\title{
$\mathrm{C}|\mathrm{E}| \mathrm{D}|\mathrm{L}| \mathrm{A} \mid \mathrm{S}$
}

Centro de Estudios

Distributivos, Laborales y Sociales

Maestría en Economía

Universidad Nacional de La Plata

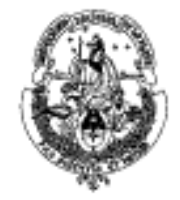

\section{Welfare Programs and Labor Supply in Developing Countries. Experimental Evidence from Latin America}

María Laura Alzúa, Guillermo Cruces y Laura Ripani

Documento de Trabajo Nro. 95

Marzo, 2010 


\title{
Welfare programs and labor supply in developing countries. Experimental evidence from Latin America
}

\author{
This version: January $31,2010^{*}$ \\ María Laura Alzúa \\ CEDLAS-Universidad Nacional de La Plata ${ }^{* *}$ \\ Guillermo Cruces \\ CEDLAS-Universidad Nacional de La Plata and CONICET \\ Laura Ripani \\ Inter-American Development Bank
}

\begin{abstract}
This paper studies the effect of welfare programs on work incentives and the labor supply of adults in developing countries. The document builds on the experimental evaluations of three programs implemented in rural areas: Mexico's PROGRESA, Nicaragua's Red de Protección Social (RPS) and Honduras' Programa de Asignación Familiar (PRAF). The impact of welfare on labor supply has been widely studied in developed countries, where most recent initiatives attempt to mitigate negative effects on work incentives. The programs under study are conditional cash transfers (CCT), which combine monetary benefits with incentives for curbing child labor and fostering the accumulation of human capital. Unlike their counterparts in developed economies, however, they do not account for potential impacts on the labor supply of adults, and there is little systematic evidence on this aspect despite a wealth of empirical studies on their intended outcomes. Comparable results for the three countries indicate mostly negative but small and non-significant effects of the programs on the employment of adults, no reallocation of labor between agricultural and other sectors, and a reduction in hours worked by adults in eligible households in RPS. Moreover, PROGRESA had a positive effect on beneficiaries' wages. The programs did not imply major disincentives to work, despite substantial transfers, but they had some effects on local labor markets. This mechanism is related to recent findings on the indirect impact of CCTs on ineligible households, and implies that future evaluation studies and designs should account for the equilibrium effects of the interventions.
\end{abstract}

Keywords: welfare programs, income support, labor supply, adult work incentives, conditional cash transfers, randomized control trials, developing countries.

JEL Codes: J08 - J22 - I38

\footnotetext{
*Corresponding authors: malzua@cedlas.org, gcruces@cedlas.org and laurari@iadb.org.

This paper originates in a section of the report "Labor supply responses to conditional cash transfer programs. Experimental and non-experimental evidence from Latin America". The full report was prepared for the IDB by a team directed by María Laura Alzúa, Guillermo Cruces, Leonardo Gasparini and Laura Ripani. The team members, Javier Alejo, Andrés Ham, Sergio Olivieri and Mariana Viollaz, from CEDLAS-UNLP, provided outstanding research assistance in different stages of the report.

The authors wish to thank Santiago Levy for encouraging this study, and Emanuel Skoufias for providing an early draft of his ongoing work. Comments by Laura Guardia, Julia Johannsen, Claudia Piras, Patrick Puhani, Graciana Rucci, Guilherme Sedlacek and Yuri Soares are much appreciated, as well as discussions with Sebastián Galiani, Fabio Veras Soares and Martín Tetaz. We also gratefully acknowledge the comments received from Felipe Barrera, Sami Berlinski, César Bouillon, Sebastián Galiani, Santiago Levy, Florencia López Boo, Craig McIntosh, Ana Santiago, and participants of the 2008 LACEA Meetings in Rio de Janeiro, from Pablo Ibarrarán, Miguel Jaramillo and other participants in the AfrEA-NONIE-3ie Conference in Cairo, March 2009, and from NEUDC 2009 participants. Andrés Ham provided excellent research assistance. The usual disclaimer applies.

The opinions in this report correspond to the authors, and do not necessarily represent those of the institutions to which they belong.

** CEDLAS-UNLP. Centro de Estudios Distributivos, Laborales y Sociales, Facultad de Ciencias Económicas, Universidad Nacional de La Plata. Calle 6 entre 47 y 48, 5to. piso, oficina 516, (1900) La Plata, Argentina. Phone: +54-(221)-422-9383. Email: cedlas@ depeco.econo.unlp.edu.ar Website: www.cedlas.org
} 


\title{
Welfare programs and labor supply in developing countries. Experimental evidence from Latin America
}

\begin{abstract}
This paper studies the effect of welfare programs on work incentives and the labor supply of adults in developing countries. The document builds on the experimental evaluations of three programs implemented in rural areas: Mexico's PROGRESA, Nicaragua's Red de Protección Social (RPS) and Honduras' Programa de Asignación Familiar (PRAF). The impact of welfare on labor supply has been widely studied in developed countries, where most recent initiatives attempt to mitigate negative effects on work incentives. The programs under study are conditional cash transfers (CCT), which combine monetary benefits with incentives for curbing child labor and fostering the accumulation of human capital. Unlike their counterparts in developed economies, however, they do not account for potential impacts on the labor supply of adults, and there is little systematic evidence on this aspect despite a wealth of empirical studies on their intended outcomes. Comparable results for the three countries indicate mostly negative but small and non-significant effects of the programs on the employment of adults, no reallocation of labor between agricultural and other sectors, and a reduction in hours worked by adults in eligible households in RPS. Moreover, PROGRESA had a positive effect on beneficiaries' wages. The programs did not imply major disincentives to work, despite substantial transfers, but they had some effects on local labor markets. This mechanism is related to recent findings on the indirect impact of CCTs on ineligible households, and implies that future evaluation studies and designs should account for the equilibrium effects of the interventions.
\end{abstract}

Keywords: welfare programs, income support, labor supply, adult work incentives, conditional cash transfers, randomized control trials, developing countries.

JEL Codes: J08 - J22 - I38

\section{Index}

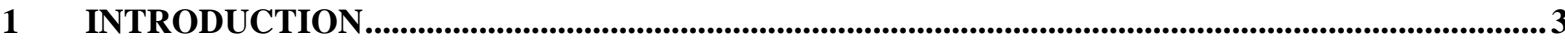

2 LABOR MARKETS AND CONDITIONAL CASH TRANSFER PROGRAMS .................................5

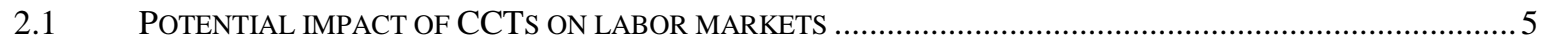

2.2 THE IMPACT OF CCTS ON LABOR MARKETS: PREVIOUS FINDINGS FOR LATIN AMERICA.....................6

3 EXPERIMENTAL EVALUATION STRATEGIES AND ESTIMATION METHODOLOGY ..........8

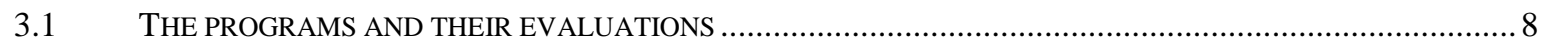

3.2 ESTIMATION AND INFERENCE WITH RANDOM ASSIGNMENT BY VILLAGE .......................................

4 CCTS AND LABOR MARKET OUTCOMES FOR ADULTS .................................................... 12

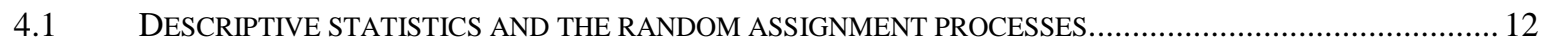

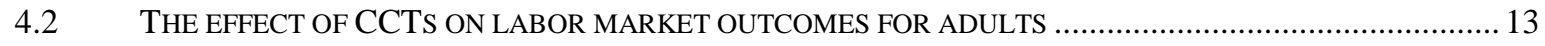

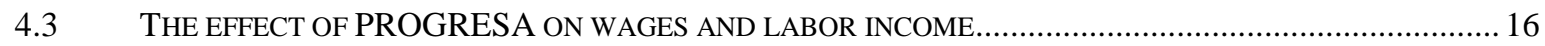

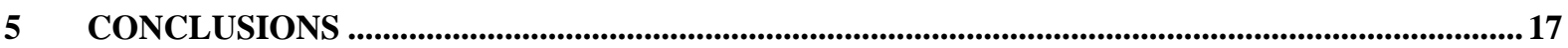

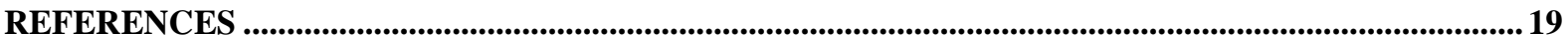

APPENDIX: BRIEF DESCRIPTION OF THE PROGRAMS ............................................................................33

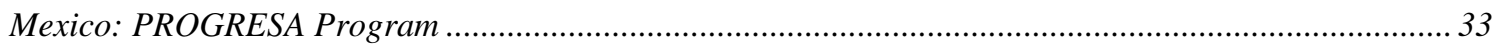

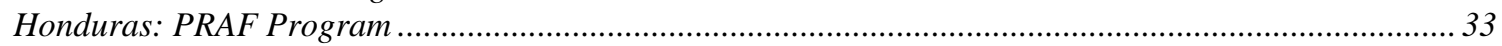

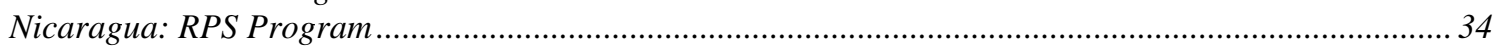

APPENDIX: ANALYSIS OF THE RANDOM ASSIGNMENT PROCESS ..............................................36 


\section{Introduction}

This paper studies the effect of welfare programs on work incentives and the labor supply of adults in developing countries. The document builds on the experimental evaluations of three programs implemented in rural areas in Latin America: Mexico's PROGRESA, Nicaragua's Red de Protección Social (RPS) and Honduras' Programa de Asignación Familiar (PRAF). The results exploit the random assignment of localities to program deployment and control groups, and present comparable estimates of impacts on adult labor supply and remuneration levels, derived from homogeneous datasets and estimation methodologies.

The impact of welfare and income support programs on labor supply has been widely studied in developed countries (Moffitt, 2002; Meghir and Phillips, 2008; Moffitt and Scholz, 2009). This literature has stressed work disincentives among recipient households, and these and other considerations have led recent reforms to incorporate sophisticated measures to mitigate these negative effects (Moffitt, 2003a; Blundell and Hoynes, 2004; Dickens, Gregg and Wadsworth, 2004; Michalopoulus, Robins and Card, 2005). The programs under study in this paper are conditional cash transfers (CCT), which combine monetary benefits with incentives for curbing child labor and fostering the accumulation of human capital. Benefit receipt is subject to a series of verifiable conditions, such as school attendance, vaccination, and regular medical checkups, among others. According to the results from a number of evaluations in Latin America, cash transfers, especially when combined with conditionalities, have proved successful in increasing welfare and human capital accumulation in recipient households, and in lowering child labor (see the reviews by Rawlings and Rubio, 2003; 2005).

Unlike their recent counterparts in the United States and Europe, however, these programs do not incorporate safeguards for their potential impact on the labor supply of adults. Moreover, there is only limited consistent systematic evidence on this aspect, despite a wealth of empirical analysis on their intended outcomes. This study attempts to establish whether there are any incentive effects of the cash transfers on the labor supply of adults in recipient households, on non-eligible individuals, and on the broader labor market equilibrium.

The main contribution of this paper is the systematic and well-identified evidence on the labor supply effects of welfare programs in developing countries. Despite its crucial role in the income generation process of the poor, there is limited evidence on labor supply 
decisions in developing countries. Existing studies indicate the presence of complex interactions between public policy, work incentives and labor allocation within households (see for instance Ardington, Case and Hosegood, 2009). Moreover, the systematic evidence presented below is derived from experimental evaluation designs, ${ }^{1}$ which have clear advantages over the policy and natural experiments underlying most of previous studies of welfare programs and labor outcomes (Angrist and Krueger, 1999; Blundell and MaCurdy, 1999; Imbens et al., 2001; Eissa et al., 2008). These evaluation strategies have also overcome some of the shortcomings of previous randomized experiments, such as those of the Negative Income Tax of the 1960s and 1970s in the United States (Ashenfelter and Plant, 1990; Moffitt, 2003b).

Comparable results for the three countries indicate mostly negative but small and nonsignificant effects of the programs on the employment of adults, no reallocation of labor between agricultural and other sectors, and a reduction in hours worked by adults in eligible households in RPS. Moreover, PROGRESA had a positive effect on beneficiaries' wages. The results indicate that the programs did not imply a major disincentive to work despite substantial transfers of up to 40 percent of household consumption, but they did have some effects on local labor markets. These findings are related to the evidence on the indirect impact of PROGRESA on the consumption of ineligible households (Angelucci and Di Giorgio, 2009), and imply that indirect and equilibrium effects should be accounted for in program design, and when assessing the programs' effects on other outcomes. These equilibrium effects also have important consequences for the interpretation of results from randomized controlled trials (see Moffitt, 2003b; Duflo et al., 2007; Heckman, 2008; and the debate between Deaton, 2009, and Imbens, 2009).

The document is organized as follows. Section 2 discusses the theoretical underpinnings of the potential impact of cash transfers on labor supply, and presents a review of the empirical evidence for countries in Latin America. Section 3 briefly reviews the programs and their evaluation strategies, and describes the estimation and inference procedures. Section 4 presents the empirical results on labor market outcomes for adults in the three programs. Conclusions follow.

\footnotetext{
${ }^{1}$ Behrman and Todd (1999), Skoufias et al. (1999) and Skoufias and Parker (2001) and Gertler (2004), among others, describe the original and well-executed experimental evaluation strategy of Mexico's PROGRESA, on which the evaluations of RPS and PRAF were based.
} 


\section{Labor markets and conditional cash transfer programs}

\subsection{Potential impact of CCTs on labor markets}

CCT programs combine short term poverty alleviation (through cash transfers) with long term objectives through incentives to human capital accumulation (school attendance, health check-ups, improved nutrition, and reduction of child labor). ${ }^{2}$ With the exception of minor training components in some programs, the overall design for CCTs in Latin America is not directly related to employment of adults in beneficiary households. There are no restrictions on work, and unlike previous workfare-like initiatives in developing countries, CCTs do not use low wage jobs as targeting mechanisms (Besley and Coate, 1992; Kanbur et al., 1994). Most importantly, earned labor income does not reduce benefit levels. In this sense, CCTs constitute a simpler policy instrument than welfare programs in developed countries: as a pure subsidy, CCTs do not induce steep replacement rates like traditional welfare programs, nor the complexity of welfare-to-work initiatives such as the US' Earned Income Tax Credit (Eissa and Liebman, 1996) or the UK's Working Family's Tax Credit (Meghir and Phillips, 2008). ${ }^{3}$

The lack of work requirements does not mean, however, that the programs are neutral in terms of adult labor supply and work incentives. The income support component and the conditionalities on children's health and education might still have affected these outcomes. Economic theory suggests several ways in which CCTs can affect work decisions within recipient households. In a standard static model of choice between consumption and leisure, the components of CCTs might play a role through at least four channels.

Firstly, the cash transfer component of the program constitutes an increase in unearned non labor income. As such, it induces a pure income effect, which loosens the budget constraint of the recipient households. The rise in unearned income might reduce hours of work if leisure is normal for beneficiaries, but the presence of fixed hour or money costs, such as commuting or childcare (Cogan, 1981; Bhattarai and Whalley, 2003) implies that a lump-sum transfer might increase labor supply.

Conditionalities constitute the second channel through which CCTs might induce behavioral responses in the labor supply of adults. The requirements related to children's

\footnotetext{
${ }^{2}$ Section 3.1 and the appendix describe the three programs under study in more detail.

${ }^{3}$ Moreover, program overlap is less of a problem for program evaluation (Moffitt, 2002) in the cases under study: PROGRESA unified several disparate programs in Mexico, while PRAF and RPS represented some of the first attempts of widespread income support in Honduras and Nicaragua.
} 
human capital accumulation might have an impact on the household's allocation of time: the positive impact of CCTs on children's school attendance might free time previously spent on childcare (Baker, Gruber and Milligan, 2008), further reducing the cost of work.

The third channel is related to the potential fall in household income due to the reduction in child labor. This effect reduces the net impact of cash transfers in households where children are induced to reduce their participation in work activities. This might result in a net reduction in total household income, and thus mitigate the transfer's potential disincentive for the labor supply of adults. ${ }^{4}$

Finally, the fourth channel operates through indirect and equilibrium effects. On the one hand, there might be indirect effects - Angelucci and Di Giorgio (2009), for instance, find impacts of PROGRESA on the consumption of ineligible households. On the other hand, changes in the labor supply schedule of beneficiaries might affect aggregate wage levels and thus remunerations for recipients and non-recipients. In the presence of such effects, the identification strategy based on the random allocation of the program would be partially compromised, because of a violation of the stable unit treatment value assumption (Angrist et al., 1996). In terms of labor supply, equilibrium effects reduce the scope for the interpretation of reduced form estimates as simple labor supply elasticities with respect to unearned income.

The combination of these four channels implies that the overall effect of CCTs on labor market outcomes for adults is ambiguous from a theoretical point of view. The presence of any impact, and its direction, is ultimately an empirical question.

\subsection{The impact of CCTs on labor markets: previous findings for Latin America}

Most of the literature evaluating the impact of CCTs focuses on the program's intended outcomes. While results vary from country to country, program evaluations show to some degree a positive effect on years of schooling, reductions in child labor and improvement in some key health indicators (Rawlings and Rubio 2003, 2005; Bouillon and Tejerina, 2006).

The labor supply of adults has been partially analysed for PROGRESA and RPS (there does not seem to be any published study for PRAF). The significant reduction in child labor for PROGRESA (Skoufias and Parker, 2001) contrasts with the lack of impact on labor

\footnotetext{
${ }^{4}$ Moreover, Ardington et al.'s (2009) results on migration from South Africa indicate that transfers might affect even more complex within-household interactions, inducing unexpected labor supply responses.
} 
market outcomes for adults in beneficiary households, according to results from Parker and Skoufias (2000) and Skoufias and Di Maro (2008) obtained from probit estimations. Both studies find no significant effects of the program on adult labor force participation within eligible households in program localities. Also in the context of PROGRESA, Angelucci and Di Giorgi (2009) find that household equivalent labor earnings for adults are not affected by the program. None of these three studies, however, exploit fully the longitudinal nature of the evaluation strategy, since they do not include fixed effects at the household or individual levels.

The impact of Nicaragua's Red de Protección Social (RPS) on the labor supply of adults is analyzed in detail by Maluccio (2007). While the studies of PROGRESA in the previous paragraph concentrated on individual labor force participation and household earnings, Maluccio (2007) studies the effect of RPS on total hours of work at the household level. The results, obtained by means of a random effects model, indicate a small but significant negative effect of the program on total household hours of work, with most of the negative impact on time spent in agricultural activities.

The discussion and results in the following pages overcomes the individual and combined limitations of these previous studies. The analysis below provides comparable results for the three programs. They are based on a common procedure for processing the original datasets, which leads to homogeneous definitions for dependent and independent variables. Moreover, the estimates for the three programs are derived from the same methodology, which takes advantage of the longitudinal and experimental nature of the evaluations by including individual and household fixed effects. Finally, while evaluations of PROGRESA concentrated on individual participation and those of RPS on household hours, the results below allow for further disaggregation, studying participation, hours of work, sector allocation and wages (when possible) for all programs. 


\section{Experimental evaluation strategies and estimation methodology}

\subsection{The programs and their evaluations}

The data used in this document corresponds to ad hoc longitudinal surveys carried out to evaluate each specific program. The three programs shared a common evaluation methodology, which implied baseline and follow up data collection in localities randomly assigned to initial program deployment and in those assigned to the control groups. The three data sources were harmonized following common criteria to achieve maximum comparability, using the methodology described in CEDLAS (2009).

The three interventions targeted rural areas in poor regions of the respective countries. The following paragraphs briefly describe the three programs' evaluation strategies, ${ }^{5}$ which were based on PROGRESA's original experimental design which randomized program deployment at the locality level, creating treatment and control groups.

In 1997, Mexico began implementing the first phase of PROGRESA. It was geographically targeted by locality, based on a poverty index. From an initial group of 506 localities selected for the first round, 320 were randomly selected to participate in the PROGRESA program (i.e., qualifying households in those localities would be eligible to participate), while the program was not deployed in the remaining 186 localities. Households in the latter localities were still subject to the data collection process, and thus constituted the control group for the program's evaluation.

The data employed in this study originates in the PROGRESA Evaluation Survey ENCEL. The estimates below are based on the initial baseline survey, and three follow-up rounds ${ }^{6}$ implemented in the subsequent semesters after the program implementation. The surveys collected socio-demographic and labor market information at the household and individual levels for all households in both treatment and control communities.

Honduras' PRAF was implemented in a set of 50 randomly selected municipalities of a total of 70, with the 20 additional municipalities forming the control group. The data in this document corresponds to a baseline survey carried out in the last quarter of 2000 and a

\footnotetext{
${ }^{5}$ The structure of each program is detailed in the appendix at the end of the paper. Further references may also be found in Todd (2004) for PROGRESA, Glewwe and Olinto (2004) for PRAF, and Maluccio and Flores (2005) for RPS.

${ }^{6}$ Baseline data was gathered between November 1997 and March 1998. The first, second and third follow ups correspond to November 1998, March 1999 and November 1999 respectively.
} 
follow-up survey in 2002. In contrast to the case of PROGRESA, where all households in treatment and control localities were interviewed, the PRAF surveys covered a sample of households. The corresponding sampling weights are used in the empirical work below.

For the case of Nicaragua's RPS, half of the poorest 42 localities were randomly assigned to the treatment group. The data used in this document corresponds to the initial baseline survey carried out in the third quarter of 2000, and the first follow-up survey conducted in 2001. As with the PRAF evaluation data, the survey consists of a sample of the targeted population, and sampling weights are used for the estimations.

Finally, despite the common characteristics, it should be noted that there were important differences in the average size of cash transfer by program. Imputing transfers from each program's eligibility rules to the evaluation samples used in this paper, the transfers represented about 4 percent of total household consumption for PRAF, 20 percent for RPS and 40 percent for PROGRESA. ${ }^{7}$ The potential effect of these differences is discussed in the empirical results section.

\subsection{Estimation and inference with random assignment by village}

The random assignment of localities in the context of the three programs under study and the availability of repeated observations implies that a differences-in-differences (DD) is the best suited estimation technique to exploit the evaluation design and identify the causal effects of the programs. A standard DD model with controls takes the form:

$$
Y_{i s t}=A_{s}+B_{t}+c X_{i s t}+\beta I_{s t}+\varepsilon_{i s t}
$$

where $Y_{i s t}$ denotes the outcome variable of interest for individual (or household) $i$ in group (or village) $s$ at time $t, I_{s t}$ is an indicator variable representing treatment status for group $s$ in time $t$ (or alternatively, an interaction between a treatment group indicator and time effects), $A_{s}$ and $B_{t}$ are group and time effects, respectively, $X_{i s t}$ is a matrix of individual characteristics and $\varepsilon_{i s t}$ is an error term. The estimate of the program impact is the coefficient $\beta$. Without the $X_{i s t}$ controls and with two time periods, the estimate of $\beta$ by ordinary least squares (OLS) is simply the difference in mean outcomes between the treatment and control groups in the

\footnotetext{
${ }^{7}$ These estimates are roughly in line with others in the literature: Maluccio (2004) reports 4 percent for PRAF, 18 percent for RPS and 20 percent for PROGRESA, although for the latter Gertler (2004) computes the average transfer as one third of total household income.
} 
two time periods. The more general case, with more than two time periods, adds a full set of time controls and interactions to account for differential evolutions over time.

The canonical DD model of equation 1 is based on repeated observations of groups over time, and without including individual controls $X_{i s t}$, the estimate of $\beta$ amounts to differences in the outcomes at the locality level. The evaluation of PROGRESA, PRAF and RPS, however, collected repeated household and individual observations, which implies that a much richer set of information is available and should be exploited (Wooldridge, 2001, 2007). Specifically, the inclusion of individual (or household) fixed effects in the estimation of equation 1 allows the identification of program effects at the individual level, rather than at locality aggregates. While these individual fixed effects were not accounted for in the studies of labor supply reviewed in the previous section, they are routinely included in evaluations of CCT's impacts on other outcomes (for instance, in Gertler's 2004 evaluation of PROGRESA's effect on health, among many others). The results below present two sets of estimates for each outcome based on equation 1: with a full set of individual controls $X_{i s t}$, and with a full set of individual fixed effects and no $X_{\text {ist }}$ variables.

With respect to the estimation methodology, the empirical results presented below are based on linear models - either OLS or fixed effects estimations of equation 1 - for binary dependent variables such as labor force participation and for continuous variables such as hours of work, wages and income. As pointed out by Angrist and Pischke (2008), linear probability model estimates do not differ substantially from those of probit or logit regressions. Moreover, coefficients on the indicator and interaction variables in equation 1 have a straightforward causal interpretation for linear estimates.

All the results below report estimates of $\beta$ in equation 1 over the full treatment and control samples, which correspond to intention to treat (ITT) coefficients. In the case of PROGRESA, the dataset contains a multidimensional targeting score and thus the eligibility status of each household. For this reason, PROGRESA's results are also computed as differences between eligible households in treatment and control localities (average treatment effect - ATE), ${ }^{8}$ and differences between ineligible households between the two sets of localities. The latter estimates correspond to Angelucci and Di Giorgio's (2009) indirect treatment effects (ITE). To account for some heterogeneous effects of the programs, the estimations are also computed by conditioning on the gender of the individual or the

\footnotetext{
${ }^{8}$ Since take up was very high among eligible households, average treatment effects and average treatment effects on the treated are roughly equivalent (Angelucci and Di Giorgio, 2009). For simplicity, the ATE terminology is adopted in the description of the results.
} 
household head, as an alternative to the inclusion of multiple interactions (Djebbari and Smith, 2008).

Finally, the standard errors in the estimations need to account for the structure of the program evaluation and implementation process. In the context of the three CCTs under study, the random assignment process did not apply directly over beneficiary households or individuals. The allocation was instead done at the geographical level. In terms of the equation above, randomization occurs at group (village) level $(s)$ instead of individual or household level $(i)$. Since the eligibility for the program is defined at the group level, the standard errors of the DD estimates should account for the likely intra-cluster correlation to avoid a potential bias. Donald and Lang (2007) attribute this bias to the fact that many of the outcomes analyzed in the literature are serially correlated, which is not usually controlled for in DD estimation - see also the discussion in Bertrand, Duflo and Mullainathan (2004 BDM henceforth). This issue might be particularly predominant in the case of the labor market outcomes covered in this study. Not accounting for this correlation across the randomization groups makes the usual OLS standard errors inconsistent, and leads to erroneous inferences of the program's causal effects.

BDM propose two methods to correct the standard errors of estimates in equation $1:^{9}$ (i) taking into account serial correlation of the outcome variable in each group $s$; this is known as cluster-robust variance estimation (CRVE) and is implemented by clustering observations by the assignment groups (e.g., localities); and (ii) estimating standard errors using block bootstrap with replacement. ${ }^{10}$ The two methods are implemented in the empirical results presented below. However, while BDM report uncorrected OLS standard errors for block bootstraps, the results below are based on Cameron, Gelbach and Miller's (2008) suggestion of reporting bootstrapped CRVE-corrected standard errors.

These corrections to the covariance matrix yield unbiased estimates of household or individual level outcomes in geographic targeting settings, accounting for potential serial correlation across groups. As a robustness check, all the estimates presented below include the two versions of the standard errors.

\footnotetext{
${ }^{9} \mathrm{BDM}$ also propose a third correction, by aggregating the data into group-year cells and estimating this model. However, only results from individual-level data are reported below.

${ }^{10}$ While in standard bootstrap methods individual observations are randomly selected with replacement from the original sample, in block bootstrap a series of consecutive observations are selected instead. In the context of program evaluation with random assignment at the geographical level, the blocks correspond to the geographical units over which the treatment was allocated.
} 


\section{CCTs and labor market outcomes for adults}

\subsection{Descriptive statistics and the random assignment processes}

This section presents the estimates of the effect of CCT programs on labor outcomes of adults using experimental evaluation data from three interventions: PRAF (Honduras), PROGRESA (Mexico), and RPS (Nicaragua).

Table 1 presents a series of descriptive statistics at the time of the baseline survey for both treatment and control localities for these three programs. These statistics allow to verify the comparability of the treatment and control groups in terms of observables, and to establish whether it is necessary to control for pre-program differences when estimating program effects.

As expected in a rural setting in developing countries, household size in all three programs is fairly large, with an average of more than six individuals per household. About 70 to 80 percent of these households include two spouses. The calculations in the tables show that treatment and control households are not significantly different in their demographic composition, with a few exceptions for some subgroups.

Table 1 also presents educational levels for treatment and control localities in each program. Enrolment rates are above 60 percent for children aged 6-11 in the three programs, with slightly higher rates when both parents are present in the household. Since the programs are targeted at poor areas in each country, the distribution of educational outcomes is concentrated on lower levels of attainment. The differences in educational achievement and enrollment rates between the treatment and control groups are small.

Finally, regarding labor market outcomes, the program datasets only allow for a simple definition of participation - individuals report if they work or if they do not. Employment varies from 52.2 (PROGRESA) to 67.9 (PRAF), and it is much higher for men than for women (about 35 percent in PRAF, 60 percent in PROGRESA and 22 percent in RPS). Employment is also higher in households with children, and in single-headed households.

The unconditional means of socio-economic and demographic statistics indicate some pre-program differences between treatment and control groups at the individual and household level. ${ }^{11}$ These results are in general agreement with preexisting reports on these

\footnotetext{
${ }^{11}$ The same is apparent in a conditional framework, as discussed in the appendix on the analysis of the random assignment process, which indicates that the resulting have some significant differences in some dimensions for the three programs.
} 
programs, which also find some significant differences among treatment and control localities (see Behrman and Todd, 1999, for PROGRESA, Glewwe and Olinto, 2004 for PRAF, and Maluccio and Flores, 2005, for RPS). Given the random assignment process in the three programs, it is likely that these differences arise because of the small number of effectively randomized units (localities). By virtue of the randomization processes, these differences reflect the composition of the resulting samples rather than selection into treatment. The estimations below control for individual characteristics or individual fixed effects to account for the ex post differences in the treatment and control samples.

\subsection{The effect of CCTs on labor market outcomes for adults}

This section presents an analysis of labor market outcomes for adults in PRAF, PROGRESA and RPS. All estimates for individuals refer to those between 15 and 80 years old, while for household outcomes the sample is restricted to household heads in the same age range.

Since the evaluation focused primarily on the programs' intended outcomes, such as children's health and education, the household surveys only have a reduced set of labor market indicators when compared to larger periodic surveys. In the three data sources employed in this study, the adult population can be partitioned into two alternate states, either as working or as not working - it is thus not possible to distinguish between inactivity and unemployment. $^{12}$ The discussion that follows refers to working, employment rates and labor supply interchangeably.

The outcomes of interest correspond to the following variables: an indicator of whether the individual is employed; the number of hours worked in all occupations in a week (for those with positive hours); an indicator for employment in agricultural activities (for those employed); and the total hours worked in the household by members aged 15 to 80 years old (this variable is computed and estimated at the household level, for households with positive hours).

As stated in the previous section, the results correspond to two alternative specifications for each outcome of interest. On the one hand, the tables report OLS estimates $\beta$ in equation 1 with a series of controls:

\footnotetext{
${ }^{12}$ It is possible to make this distinction for RPS, but to maintain comparable results the results below report those for the same variable for the three programs.
} 
- Controls for individual characteristics: gender (if applicable), household size, an indicator for bi-parental household, number of children, age of the individual, age squared, and educational indicators (complete primary through complete college).

- Controls for household characteristics: the gender of the household head (if applicable), household size, an indicator for bi-parental household, number of children of the head of household, a dummy variable indicating if at least one child in the household attends school, and indicators for the household head's educational level.

The fixed effect estimations, on the other hand, do not include any individual controls, since most of those listed above are time invariant or have low variability. All estimations include time effects, treatment indicators, interactions between the two, and locality controls. As described in the previous section, the results also report cluster-robust standard errors and cluster-robust standard errors by block-bootstrap at the locality level with 300 replications. Finally, the results present estimates for the intention to treat (ITT) for the three programs and for males and females separately. For the specific case of PROGRESA, the availability of eligibility status implies that average treatment effects (ATE) and indirect treatment effects (ITE) can also be computed. The tables only report the relevant coefficient for the treatment effects (the coefficient $\beta$ ). ${ }^{13}$

The estimates for PRAF correspond to the simple two-period case (baseline in second half of 2000, follow up in May-August 2002), while estimates for RPS and PROGRESA include multiple consecutive follow up surveys. ${ }^{14}$ RPS' baseline was carried out in AugustSeptember 2000, with a first follow up in October 2001 and a second one in October 2002. For PROGRESA, the baseline corresponds to September 1997-March 1998, and the follow up data was collected in November 1998, March 1999 and November 1999.

Tables 2 and 3 report the main results for the employment status of adults in the three programs. The columns show the estimated coefficient of the time-treatment indicator in the regression, with the two alternative estimates of the standard errors (cluster-adjusted and block-bootstrapped).

Table 2 presents the results for Honduras's PRAF and Nicaragua's RPS. The estimates of the programs' effects on employment are mostly negative, ranging from -0.5 to 1.8 percentage points for PRAF, and from -0.2 to -2.3 percentage points for RPS (with

\footnotetext{
${ }^{13}$ Full regression outputs for all estimations are available from the authors upon request.

${ }^{14}$ The tables report the effect by round of the evaluation survey, and correspond to the difference between the round and the baseline (pre-program) levels. These effects are estimated jointly by multiple time and treatment interactions, and not as separate regressions by follow up period.
} 
positive effects for males in the first follow up survey), and the effects are higher in absolute value for females than for males. None of these estimates, however, are different from zero at standard significance levels.

Table 3 presents the results from Mexico's PROGRESA. The coefficients on employment estimated jointly for males and females are also negative, and in the same range as those reported in Table 2 (from about -0.1 to -2.6 percentage points). However, none of them appear to be consistently significant for all three follow up periods or for both OLS and FE estimations. The exception is the case of ITE (estimates for individuals in ineligible households) corresponding to the third follow up survey, which seems to be driven mostly by a fairly large fall (about 3.5-5.1 percentage points) in employment among ineligible females in the third follow up survey. The inconsistency of this result for other time periods implies that this is probably a statistical artifact.

Occupational choice is another labor market outcome that might be affected by CCTs and related programs. For instance, Skoufias et al. (2008) find that the PAAL program in Mexico induced workers to move away from agricultural work, supporting the idea that such work acts as food insurance. For this purpose, the regressions in Tables 4 and 5 present the results for regressions where the dependent variable is an indicator for employed individuals equal to one if they work in agricultural occupations, and zero otherwise.

The coefficients reported in Tables 4 and 5 indicate that none of the three programs had statistically significant effects on labor allocation to agricultural or other sectors. The results do not indicate a clear pattern across time or estimations methodologies either, so the lack of significance is probably not due to lack of statistical power.

This emerging pattern of non-significant effects of the programs on labor market outcomes for adults is confirmed by the results presented in Tables 6 and 7, in which the dependent variable is the number of hours worked (for individuals with strictly positive reported hours). The estimates for PRAF are consistently positive and small (from about 0.5 to about 1.85 hours per week), while those for RPS are consistently negative (from about -1.5 to about -5.7$)$, and higher in absolute value for women (-3 to -5.6 depending on the follow up and estimation method). The results for PROGRESA in Table 7 do not indicate a clear pattern. Taken together, the evidence indicates that there are no significant effects on individual hours of work for any of the programs.

Tables 8 and 9 present the impact of the programs on total hours of work by adults in a household (these are household, not individual estimates). The results for PRAF in Table 8 are similar to those in Table 6, with positive but non-significant effects on hours, especially 
in female-headed households. The results for RPS, however, exhibit a clear and significant pattern: hours of work fell significantly, by about 4.7-6.3 hours by the time of the second follow up survey (a year after the baseline), and this result is driven mainly by a large and strongly significant fall in hours worked by adults in female headed households (14.8-16 weekly hours). These results are compatible with Maluccio's (2007) findings for RPS, based on random effects estimation. Finally, the results for PROGRESA in Table 9 indicate small and not statistically significant results on this household aggregate.

Summing up, none of the three CCT programs exhibited major impacts on labor market outcomes for adults. Employment levels and the sectoral allocation of work among those working were not fundamentally transformed by either of the programs. The most notable result was a reduction of hours of work at the household level for RPS, especially in female headed households. While average benefits were substantial in RPS and small in PRAF (with respect to household consumption levels), they were even larger in PROGRESA, suggesting that subsidy levels were not necessarily the main factor at work. The overall results indicate that program effects operate, if anything, through adjustments in the intensive (hours) rather than the extensive (participation) margin. However, the analysis of employment and hours in the labor market is necessarily partial, since program effects might be manifested through prices rather than quantities. The following section studies the effect of PROGRESA on wages and labor income (this information was not collected by the PRAF and RPS evaluation surveys).

\subsection{The effect of PROGRESA on wages and labor income}

Tables 10 and 11 present the effects of PROGRESA ${ }^{15}$ on individual hourly wages (available only for the first and third follow up) and household labor income per adult.

Table 10 indicates that PROGRESA had a sizeable effect on eligible individuals, increasing hourly wages by about 5-7 percent - these results are significant at the 5 and 10 percent levels for FE estimations (ATE and ITT, respectively), with similar OLS coefficients and standard errors. Moreover, these results seem to be driven fundamentally by males none of the coefficients for females are significant, and neither are any of the indirect treatment effect estimates.

\footnotetext{
${ }^{15}$ The PRAF and RPS evaluation surveys did not include questions on earnings or wages.
} 
Finally, these higher hourly wages are also reflected in higher levels of household labor income for adult, since hours of work were mostly unchanged by PROGRESA. This effect is reported in Table 11, which indicates an increase of about 5.3 to 7.4 percent, concentrated in the third round of the follow up (a year after the baseline) and among male headed households. These results contrast with those in Angelucci and Di Giorgio's (2009, Table 5), who report no significant effect of PROGRESA on monthly adult equivalent labor earnings. The estimates presented here, however, include individual controls (for OLS regressions) and individual fixed effects (for FE regressions), whereas Angelucci and Di Giorgio (2009) only include locality fixed effects. The results in Tables 10 and 11 are thus closer to estimates of changes in labor market outcomes at the individual level, rather than at the locality level.

Even with no discernible impact on labor force participation or hours of work, PROGRESA had an effect on local labor markets by increasing the wage and labor income of males in eligible households.

\section{Conclusions}

This paper studied the effect of welfare programs on work incentives and the labor supply of adults in developing countries. The estimates built on the experimental evaluations of three programs implemented in rural areas: Mexico's PROGRESA, Nicaragua's Red de Protección Social (RPS) and Honduras’ Programa de Asignación Familiar (PRAF).

The empirical results indicate that none of the three programs induced a major shift in the labor force participation of adults. However, the analysis uncovered a significant reduction in hours worked among adults in Nicaragua's RPS, and a positive and significant effect of Mexico's PROGRESA on wages for males in eligible households. These two programs had relatively high benefit levels. There were no significant impacts on labor market outcomes in the case of Honduras' PRAF, which had low levels of monetary transfers.

This evidence suggests that while CCT programs in poor rural areas with high benefit levels do not imply a substantial disincentive to work, they might still affect equilibrium in the labor market. Equilibrium effects in this context should not be surprising: for instance, in PROGRESA's original implementation about half of the households in treatment localities received a transfer equivalent to 40 percent of their income. The aggregate effect of such large and widespread transfers had an impact at the community level beyond eligible 
households, as reflected in Angelucci and Di Giorgio's (2009) results on the consumption of ineligible households.

These results have important implications for evaluation design and for the deployment and extension of the program. For impact evaluation, equilibrium effects complicate the interpretation of reduced form estimates from randomized controlled experiments, which is an old discussion in the analysis of welfare programs - see Browning's (1971) critique of Orcutt and Orcutt's (1968) randomized negative income tax experiments based on feedback effects of wages. In terms of the empirical results presented here, the programs' impacts can be attributed to shifts in the labor supply of adults in eligible households, but it is not possible to rule out further effects through program-induced aggregate changes in labor demand. Moreover, in the case of CCTs with intended outcomes in multiple dimensions, indirect effects on labor market outcomes might be confounded with the direct impact of the transfers and the conditionalities.

The results do not necessarily imply that work disincentives should not be accounted for in the design of welfare programs in developing countries. While not overly relevant in the three cases analyzed in this paper, the external validity of these results does not necessarily extend to interventions in other contexts, or to the extension of existing CCTs to urban areas. 


\section{References}

Angelucci, M. and De Giorgi, G. (2009): "Indirect Effects of an Aid Program: How Do Cash Transfers Affect Ineligibles' Consumption?", American Economic Review 99:1, 486508

Angrist, J. and Krueger, A. (1999): "Empirical strategies in labor economics." In Ashenfelter, Orley C., ed.; Card, David, ed. Handbook of labor economics, Vol. 3A, 2097 NorthHolland.

Angrist, J. and Pischke, J. (2008): Mostly Harmless Econometrics: An Empiricist's Companion, Princeton University Press.

Angrist, J., Imbens, G., and Rubin, D. (1996): "Identification of Causal effects Using Instrumental Variables," Journal of the American Statistical Association, Vol. 91, No. 434, pp. 444-455.

Ardington, C., Case, A. and Hosegood, V. (2009): "Labor Supply Responses to Large Social Transfers: Longitudinal Evidence from South Africa", American Economic Journals: Applied Economics, Vol. 1, N. 1.

Ashenfelter, O. and Plant, M. (1990): "Nonparametric Estimates of the Labor-Supply Effects of Negative Income Tax Programs", Journal of Labor Economics, Vol. 8, No. 1.

Attanasio, O., Meghir, C. and Székely, M. (2003): "Using randomized experiments and structural models for 'scaling up': evidence from the PROGRESA evaluation," IFS Working Paper EWP04/03, ISSN: 1742-0415.

Baker, M., Gruber, J. and Milligan, K (2008): "Universal Child Care, Maternal Labor Supply, and Family Well-Being," Journal of Political Economy, vol. 116(4), pages 709-745, 08 .

Behrman, J. and Todd, P. (1999): "Randomness in the Experimental Samples of PROGRESA (Education, Health and Nutrition Program)", report submitted to PROGRESA, International Food Policy Research Institute, Washington D.C.

Bertrand, M., Duflo, E., and Mullainathan, S. (2004): "How Much Should We Trust Differences in differences Estimates?", The Quarterly Journal of Economics vol. 119(1), pages 249-275.

Besley, T. and Coate, S. (1992): "Workfare versus Welfare: Incentive Arguments for Work Requirements in Poverty Alleviation Programs," American Economic Review, 82, 1: 249- 261.

Bhattarai, K. and Whalley, J. (2003): "Discreteness And The Welfare Cost Of Labor Supply Tax Distortions", International Economic Review vol 44(3), pages 1117-1133.

Blundell, R. and Hoynes, H. (2004): "Has 'In-Work' Benefit Reform Helped the Labor Market?," in NBER Seeking a Premier Economy: The Economic Effects of British Economic Reforms, 1980-2000, pages 411-460, National Bureau of Economic Research

Blundell, R. and MaCurdy, T. (1999): "Labor Supply: A Review of Alternative Approaches", In Ashenfelter, Orley C., ed.; Card, David, ed. Handbook of labor economics, Vol. 3A, 2097 North-Holland. 
Bouillon, C. and Tejerina, L. (2006): "Do We Know What Works? A Systematic Review of Impact Evaluations of Social Programs in Latin America and the Caribbean", InterAmerican Development Bank, Sustainable Development Department, Poverty and Inequality Unit.

Browning, E. (1971): "Incentive and Disincentive Experimentation for Income Maintenance Policy Purposes: Note", American Economic Review, Vol. 61, No. 4.

Cameron, A., Gelbach, J. and Miller, D. (2008): "Bootstrap-Based Improvements for Inference with Clustered Errors", The Review of Economics and Statistics vol. 90(3), pages $414-427$.

CEDLAS (2009): "A Guide to the SEDLAC: Socioeconomic Database for Latin America and the Caribbean", Technical report, CEDLAS and The World Bank. Available online at www.cedlas.org.

Cogan, J. (1981): "Fixed Costs and Labor Supply", Econometrica vol. 49(4), pages 945-963.

Deaton, A. (2009): "Instruments of development: randomization in the tropics, and the search for the elusive keys to economic development”, NBER Working Paper 14690.

Dickens, R., Gregg, P. and Wadsworth, J., eds. (2004), The Labour Market Under New Labour: the state of working Britain, London: Palgrave Macmillan.

Djebbari, H. and Smith, J. (2008): "Heterogeneous impacts in PROGRESA," Journal of Econometrics, vol. 145(1-2), pages 64-80.

Donald, S., and Lang, K. (2007): "Inference with Differences in Differences and Other Panel Data". The Review of Economics and Statistics vol. 89(2), pages 221-233.

Duflo, E., Glennerster, R. and Kremer, M. (2007): "Using Randomization in Development Economics Research: A Toolkit", Centre for Economic Policy Research, Discussion Paper No. 6059.

Eissa, N. and Liebman, J. (1996), "Labor Supply Response to the Earned Income Tax Credit", The Quarterly Journal of Economics vol. 111(2), pages 605-37.

Eissa, N., Kleven, H. and Kreiner, C. (2008): "Evaluation of Four Tax Reforms in the United States: Labor Supply and Welfare Effects for Single Mothers," Journal of Public Economics 92, 3-4.

Gertler, P. (2004): "Do Conditional Cash Transfers Improve Child Health? Evidence from PROGRESA's Control Randomized Experiment”, The American Economic Review vol. 94(2), pages 336-341.

Glewwe, P. and Olinto, P. (2004): "Evaluating the Impact of Conditional Cash Transfers on Schooling: An Experimental Analysis of Honduras's PRAF Program". Final Report for USAID.

Heckman, J. (2008): “Econometric Causality,” International Statistical Review, vol. 76(1), pages $1-27,04$.

IFPRI (2000): PRAF, Third Report: Monitoring and Evaluation System, IFPRI, Washington DC.

Imbens, G. (2009): "Better LATE Than Nothing: Some Comments on Deaton (2009) and Heckman and Urzua (2009)", mimeo, Harvard University, April 2009. 
Imbens, G., Rubin, D. and Sacerdote, B. (2001): "Estimating the Effect of Unearned Income on Labor Earnings, Savings and Consumption: Evidence from a Survey of Lottery Players", American Economic Review vol. 91(4), pages 779-794.

Kanbur, R., Keen, M. and Tuomala, M. (1994): "Labor Supply and Targeting in Poverty Alleviation Programs," World Bank Economic Review, vol. 8(2), pages 191-211.

Maluccio, J. (2004): "Effects of Conditional Cash Transfer Programs on Current Poverty, Consumption, and Nutrition". Presentation at the Second International Workshop on Conditional Cash Transfer Programs, São Paulo, Brazil - April 2004.

Maluccio, J. (2007): "The Impact of Conditional Cash Transfers in Nicaragua on Consumption, Productive Investments, and Labor Allocation", ESA Working Paper No. 07-11, Agricultural and Development Economics Division, UN's Food and Agriculture Organization.

Maluccio, J. and Flores, R. (2005): "Impact Evaluation of a Conditional Cash Transfer Program the Nicaraguan Red de Protección Social”, Report 141, International Food Policy Research Institute, Washington, DC.

Meghir, C. and Phillips, D. (2008): "Labour Supply And Taxes", Institute For Fiscal Studies WP08/04, London.

Michalopoulos, C., Robins, P. and Card, D. (2005): "When financial work incentives pay for themselves: evidence from a randomized social experiment for welfare recipients," Journal of Public Economics, vol. 89(1), pages 5-29.

Moffitt, R. (2002): "Welfare programs and labor supply," Chapter 34 in Auerbach, A. and Feldstein, M. (ed.), Handbook of Public Economics, edition 1, volume 4, Elsevier.

Moffitt, R. (2003a): "The Negative Income Tax and the Evolution of U.S. Welfare Policy," Journal of Economic Perspectives, vol. 17(3), pages 119-140.

Moffitt, R. (2003b): “The Role of Randomized Field Trials in Social Science Research: A Perspective from Evaluations of Reforms of Social Welfare Programs," NBER Technical Working Papers 0295, National Bureau of Economic Research.

Moffitt, R. and Scholz, J. (2009): "Trends in the Level and Distribution of Income Support," NBER Working Papers 15488, National Bureau of Economic Research.

Orcutt, G. and Orcutt, A. (1968): "Incentive and Disincentive Experimentation for Income Maintenance Policy Purposes”, American Economic Review, Vol. 58, No. 4.

Parker, S. and Skoufias, E. (2000): "The impact of PROGRESA on work, leisure, and time allocation". Final report, International Food Policy Research Institute. Available online at: www.ifpri.org/themes/Progresa/timeallocation.htm, accessed June 2008.

Rawlings, L. and Rubio, G. (2003): "Evaluating the Impact of Conditional Cash Transfer Programs: Lessons from Latin America", World Bank Policy Research Working Paper No. 3119.

Rawlings, L. and Rubio, G. (2005): "Evaluating the impact of conditional cash transfer programs". The World Bank Research Observer vol. 20(1), pages 29-55.

Robins, P. (1985): "A Comparison of the Labor Supply Findings from the Four Negative Income Tax Experiments", Journal of Human Resources, Vol. 20, No. 4.

Skoufias, E. and Di Maro, V. (2008): "Conditional Cash Transfers, Adult Work Incentives, and Poverty", Journal of Development Studies vol. 44(7), pages 935-960, 
Skoufias, E., and Parker, S. (2001): "Conditional Cash Transfers and their Impact on Child Work and Schooling: Evidence from the PROGRESA Program in Mexico", Economía, Vol. 2, Number 1, Fall 2001.

Skoufias, E., Davis, B. and Behrman, J. (1999): "An Evaluation of the Selection of Beneficiary Households in the Education, Health, and Nutrition Program (PROGRESA) of Mexico", report submitted to PROGRESA. International Food Policy Research Institute, Washington, D.C.

Skoufias, E., Unar, M. and González-Cossío, T. (2008): “The Impacts of Cash and In-Kind Transfers on Consumption and Labor Supply: Experimental Evidence from Rural Mexico", Policy Research Working Paper 4778, World Bank.

Todd, P. (2004): "Design of the Evaluation and Method Used to Select Comparison Group Localities for the Six-Year Follow-up Evaluation of Oportunidades in Rural Areas". Technical note, SEDESOL, Mexico.

Wooldridge, J. (2001): Econometric Analysis of Cross Section and Panel Data, MIT Press.

Wooldridge, J. (2007): "Difference-in-Differences Estimation. Lecture notes 10". Guido Imbens and James Wooldridge course "What's new in econometrics", NBER, Summer'07. 
Table 1

Descriptive Statistics by program

\begin{tabular}{|c|c|c|c|c|c|c|}
\hline & \multicolumn{2}{|c|}{ PRAF (Baseline: Aug.-Dec. 2000) } & \multicolumn{2}{|c|}{ PROGRESA (Baseline: Sept. 97-Mar. 98) } & \multicolumn{2}{|c|}{ RPS (Baseline: Aug.-Sept. 2000) } \\
\hline & Treatment & Control & Treatment & Control & Treatment & Control \\
\hline \multicolumn{7}{|l|}{ Households } \\
\hline All & 34,455 & 29,538 & 14,856 & 9,221 & 5,781 & 4,203 \\
\hline Eligible (\%) & & & 52.8 & 50.8 & & \\
\hline Spouse present (\%) & $\begin{array}{c}77.4 \\
(1.06)\end{array}$ & $\begin{array}{c}73.9 \\
(1.10)\end{array}$ & $\begin{array}{c}81.9 \\
(0.32)\end{array}$ & $\begin{array}{c}82.3 \\
(0.40)\end{array}$ & $\begin{array}{c}81.4 \\
(1.37)\end{array}$ & $\begin{array}{c}79.4 \\
(1.46)\end{array}$ \\
\hline Mean household size & $\begin{array}{c}6.6 \\
(0.03)\end{array}$ & $\begin{array}{c}6.6 \\
(0.03)\end{array}$ & $\begin{array}{c}6.5 \\
(0.01)\end{array}$ & $\begin{array}{c}6.5 \\
(0.01)\end{array}$ & $\begin{array}{c}7.5 \\
(0.05)\end{array}$ & $\begin{array}{c}7.5 \\
(0.05)\end{array}$ \\
\hline Mean number of children & $\begin{array}{c}3.4 \\
(0.03)\end{array}$ & $\begin{array}{c}3.2 \\
(0.03)\end{array}$ & $\begin{array}{c}3.3 \\
(0.01)\end{array}$ & $\begin{array}{c}3.2 \\
(0.01)\end{array}$ & $\begin{array}{c}3.3 \\
(0.04)\end{array}$ & $\begin{array}{c}3.3 \\
(0.03)\end{array}$ \\
\hline \multicolumn{7}{|l|}{ Individuals } \\
\hline \multicolumn{7}{|l|}{ Years of Education } \\
\hline All & $\begin{array}{c}3.4 \\
(0.05)\end{array}$ & $\begin{array}{c}2.9 \\
(0.04)\end{array}$ & $\begin{array}{c}5.2 \\
(0.02)\end{array}$ & $\begin{array}{c}5.1 \\
(0.02)\end{array}$ & $\begin{array}{c}2.3 \\
(0.05)\end{array}$ & $\begin{array}{c}2.2 \\
(0.05)\end{array}$ \\
\hline Females & $\begin{array}{c}3.4 \\
(0.07)\end{array}$ & $\begin{array}{c}2.7 \\
(0.06)\end{array}$ & $\begin{array}{c}5.1 \\
(0.02)\end{array}$ & $\begin{array}{c}5.1 \\
(0.03)\end{array}$ & $\begin{array}{c}2.3 \\
(0.07)\end{array}$ & $\begin{array}{c}2.3 \\
(0.07)\end{array}$ \\
\hline Males & $\begin{array}{c}3.4 \\
(0.06)\end{array}$ & $\begin{array}{c}3.1 \\
(0.06)\end{array}$ & $\begin{array}{c}5.2 \\
(0.02)\end{array}$ & $\begin{array}{c}5.1 \\
(0.03)\end{array}$ & $\begin{array}{c}2.2 \\
(0.07)\end{array}$ & $\begin{array}{c}2.1 \\
(0.07)\end{array}$ \\
\hline \multicolumn{7}{|l|}{ Employment } \\
\hline All & $\begin{array}{c}66.3 \\
(0.78)\end{array}$ & $\begin{array}{c}64.5 \\
(0.76)\end{array}$ & $\begin{array}{c}53.1 \\
(0.24)\end{array}$ & $\begin{array}{c}51.2 \\
(0.30)\end{array}$ & $\begin{array}{c}56.2 \\
(0.98)\end{array}$ & $\begin{array}{c}57.7 \\
(1.00)\end{array}$ \\
\hline Females & $\begin{array}{c}34.4 \\
(1.22)\end{array}$ & $\begin{array}{c}32.3 \\
(1.13)\end{array}$ & $\begin{array}{c}19.5 \\
(0.27)\end{array}$ & $\begin{array}{c}16.8 \\
(0.31)\end{array}$ & $\begin{array}{c}20.4 \\
(1.15)\end{array}$ & $\begin{array}{c}23.2 \\
(1.22)\end{array}$ \\
\hline Males & $\begin{array}{c}90.0 \\
(0.64)\end{array}$ & $\begin{array}{c}88.3 \\
(0.67)\end{array}$ & $\begin{array}{c}86.4 \\
(0.23)\end{array}$ & $\begin{array}{c}85.7 \\
(0.30)\end{array}$ & $\begin{array}{c}90.5 \\
(0.81)\end{array}$ & $\begin{array}{c}91.7 \\
(0.79)\end{array}$ \\
\hline Households with spouse & $\begin{array}{c}66.0 \\
(0.87)\end{array}$ & $\begin{array}{c}65.3 \\
(0.85)\end{array}$ & $\begin{array}{c}52.4 \\
(0.26)\end{array}$ & $\begin{array}{c}50.8 \\
(0.32)\end{array}$ & $\begin{array}{c}56.0 \\
(1.07)\end{array}$ & $\begin{array}{c}57.1 \\
(1.10)\end{array}$ \\
\hline Households without spouse & $\begin{array}{c}67.4 \\
(1.77)\end{array}$ & $\begin{array}{c}61.3 \\
(1.64)\end{array}$ & $\begin{array}{c}57.4 \\
(0.62)\end{array}$ & $\begin{array}{c}53.5 \\
(0.79)\end{array}$ & $\begin{array}{c}57.0 \\
(2.54)\end{array}$ & $\begin{array}{c}60.5 \\
(2.42)\end{array}$ \\
\hline Households with children & $\begin{array}{c}67.2 \\
(0.87)\end{array}$ & $\begin{array}{c}66.1 \\
(0.86)\end{array}$ & $\begin{array}{c}53.2 \\
(0.27)\end{array}$ & $\begin{array}{c}51.6 \\
(0.34)\end{array}$ & $\begin{array}{c}56.8 \\
(1.11)\end{array}$ & $\begin{array}{c}58.4 \\
(1.13)\end{array}$ \\
\hline Households without children & $\begin{array}{c}62.9 \\
(1.75)\end{array}$ & $\begin{array}{c}59.3 \\
(1.59)\end{array}$ & $\begin{array}{c}52.8 \\
(0.49)\end{array}$ & $\begin{array}{c}49.9 \\
(0.61)\end{array}$ & $\begin{array}{c}53.8 \\
(2.13)\end{array}$ & $\begin{array}{c}55.3 \\
(2.19)\end{array}$ \\
\hline \multicolumn{7}{|l|}{ Agricultural Workers } \\
\hline All & $\begin{array}{c}65.3 \\
(0.98)\end{array}$ & $\begin{array}{c}64.4 \\
(0.95)\end{array}$ & $\begin{array}{c}76.9 \\
(0.35)\end{array}$ & $\begin{array}{c}74.7 \\
(0.44)\end{array}$ & $\begin{array}{c}83.7 \\
(0.98)\end{array}$ & $\begin{array}{c}80.9 \\
(1.06)\end{array}$ \\
\hline Females & $\begin{array}{c}33.0 \\
(2.32)\end{array}$ & $\begin{array}{c}33.8 \\
(2.02)\end{array}$ & $\begin{array}{c}41.8 \\
(1.09)\end{array}$ & $\begin{array}{c}32.7 \\
(1.28)\end{array}$ & $\begin{array}{c}57.2 \\
(3.25)\end{array}$ & $\begin{array}{c}42.2 \\
(3.11)\end{array}$ \\
\hline Males & $\begin{array}{c}74.5 \\
(0.99)\end{array}$ & $\begin{array}{c}72.7 \\
(0.99)\end{array}$ & $\begin{array}{c}82.6 \\
(0.34)\end{array}$ & $\begin{array}{c}81.3 \\
(0.42)\end{array}$ & $\begin{array}{c}89.2 \\
(0.90)\end{array}$ & $\begin{array}{c}90.5 \\
(0.88)\end{array}$ \\
\hline \multicolumn{7}{|l|}{ Mean hours of work } \\
\hline All & $\begin{array}{c}38.2 \\
(0.21)\end{array}$ & $\begin{array}{c}37.7 \\
(0.20)\end{array}$ & $\begin{array}{c}43.4 \\
(0.10)\end{array}$ & $\begin{array}{c}43.7 \\
(0.12)\end{array}$ & $\begin{array}{c}39.4 \\
(0.42)\end{array}$ & $\begin{array}{c}38.0 \\
(0.44)\end{array}$ \\
\hline Females & $\begin{array}{c}33.0 \\
(0.69)\end{array}$ & $\begin{array}{c}32.4 \\
(0.59)\end{array}$ & $\begin{array}{c}41.5 \\
(0.28)\end{array}$ & $\begin{array}{c}42.3 \\
(0.39)\end{array}$ & $\begin{array}{c}33.1 \\
(1.28)\end{array}$ & $\begin{array}{c}31.2 \\
(1.17)\end{array}$ \\
\hline Males & $\begin{array}{c}39.6 \\
(0.19) \\
\end{array}$ & $\begin{array}{c}39.1 \\
(0.19)\end{array}$ & $\begin{array}{c}43.8 \\
(0.10) \\
\end{array}$ & $\begin{array}{c}44.0 \\
(0.12)\end{array}$ & $\begin{array}{c}41.0 \\
(0.40)\end{array}$ & $\begin{array}{c}40.2 \\
(0.43)\end{array}$ \\
\hline
\end{tabular}

Source: Own calculations on Program Evaluation Surveys

Standard Errors in Parentheses 
Table 2

Program effects on employment, PRAF \& RPS

\begin{tabular}{|c|c|c|c|c|c|c|}
\hline \multirow[b]{3}{*}{ PRAF } & \multicolumn{6}{|c|}{ DD Estimates } \\
\hline & \multicolumn{2}{|c|}{ ITT } & \multicolumn{2}{|c|}{ ITT Males } & \multicolumn{2}{|c|}{ ITT Females } \\
\hline & OLS & FE & OLS & FE & OLS & $\mathrm{FE}$ \\
\hline \multicolumn{7}{|c|}{ Baseline: Aug-Dec. 2000} \\
\hline $\mathrm{t}=1$ (May-Aug. 2002) & -0.011 & -0.015 & -0.005 & -0.012 & -0.010 & -0.018 \\
\hline Clustered & $(0.016)$ & $(0.015)$ & $(0.017)$ & $(0.018)$ & $(0.023)$ & $(0.028)$ \\
\hline Boostrapped & $(0.017)$ & $(0.015)$ & $(0.018)$ & $(0.019)$ & $(0.023)$ & $(0.031)$ \\
\hline Observations & 12,833 & 12,482 & 7,145 & 6,930 & 5,688 & 5,552 \\
\hline Groups & & 7,484 & & 3,918 & & 3,569 \\
\hline \multicolumn{7}{|c|}{$\begin{array}{l}\text { RPS } \\
\text { Baseline: Aug-Sept. } 2000\end{array}$} \\
\hline $\mathrm{t}=1$ (Oct. 2001) & -0.005 & -0.002 & 0.009 & 0.006 & -0.022 & -0.010 \\
\hline Clustered & $(0.020)$ & $(0.020)$ & $(0.020)$ & $(0.020)$ & $(0.030)$ & $(0.029)$ \\
\hline Boostrapped & $(0.020)$ & $(0.021)$ & $(0.020)$ & $(0.020)$ & $(0.030)$ & $(0.028)$ \\
\hline $\mathrm{t}=2$ (Oct. 2002) & -0.012 & -0.013 & -0.009 & -0.005 & -0.020 & -0.023 \\
\hline Clustered & $(0.018)$ & $(0.019)$ & $(0.014)$ & $(0.014)$ & $(0.030)$ & $(0.031)$ \\
\hline Boostrapped & $(0.018)$ & $(0.020)$ & $(0.015)$ & $(0.014)$ & $(0.031)$ & (0.032) \\
\hline Observations & 11,241 & 11,287 & 5,828 & 5,852 & 5,413 & 5,435 \\
\hline Groups & & 4,426 & & 2,300 & & 2,126 \\
\hline
\end{tabular}

Source: Own calculations based on program evaluation surveys

Standard errors in parentheses.

Bootstrapped errors obtained by CRVE-Block Bootstrap with 300 replications.

* Significant at $10 \%$; ** significant at 5\%; *** significant at $1 \%$ 
Table 3

Program effect on employment, PROGRESA

\begin{tabular}{|c|c|c|c|c|c|c|c|c|c|c|c|c|c|c|c|c|c|c|}
\hline \multirow{3}{*}{$\begin{array}{l}\text { PROGRESA } \\
\text { Baseline: Sept. 97-Mar. } 98\end{array}$} & \multicolumn{18}{|c|}{ DD Estimates } \\
\hline & \multicolumn{2}{|c|}{$1 \pi T$} & \multicolumn{2}{|c|}{ ATE } & \multicolumn{2}{|c|}{ ITE } & \multicolumn{2}{|c|}{ ITT Males } & \multicolumn{2}{|c|}{ ITT Females } & \multicolumn{2}{|c|}{ ATE Males } & \multicolumn{2}{|c|}{ ATE Females } & \multicolumn{2}{|c|}{ ITE Males } & \multicolumn{2}{|c|}{ ITE Females } \\
\hline & OLS & $\mathrm{FE}$ & OLS & $\mathrm{FE}$ & OLS & $\mathrm{FE}$ & OLS & FE & OLS & FE & OLS & FE & OLS & FE & OLS & FE & OLS & FE \\
\hline$=1$ (Nov. 98) & -0.007 & -0.008 & -0.003 & -0.003 & -0.014 & -0.015 & -0.004 & -0.001 & -0.009 & -0.008 & 0.004 & 0.003 & -0.004 & 0.003 & -0.012 & -0.014 & -0.019 & -0.020 \\
\hline Clustered & $(0.008)$ & $(0.008)$ & $(0.010)$ & $(0.010)$ & $(0.009)$ & $(0.009)^{\star}$ & $(0.009)$ & $(0.008)$ & $(0.015)$ & $(0.013)$ & $(0.012)$ & $(0.010)$ & $(0.019)$ & $(0.016)$ & $(0.011)$ & $(0.011)$ & $(0.017)$ & $(0.017)$ \\
\hline Boostrapped & $(0.008)$ & $(0.007)$ & $(0.011)$ & $(0.010)$ & $(0.009)$ & $(0.009)^{*}$ & $(0.008)$ & $(0.007)$ & $(0.016)$ & $(0.014)$ & $(0.012)$ & $(0.010)$ & $(0.019)$ & $(0.016)$ & $(0.011)$ & $(0.010)$ & $(0.018)$ & $(0.017)$ \\
\hline $\mathrm{t}=2$ (Mar. 99$)$ & -0.014 & -0.009 & -0.012 & -0.009 & -0.026 & -0.014 & -0.003 & 0.004 & -0.021 & -0.021 & -0.002 & -0.001 & -0.015 & -0.019 & -0.005 & -0.005 & -0.044 & -0.024 \\
\hline Clustered & $(0.007)^{\star \star}$ & $(0.007)$ & $(0.009)$ & $(0.009)$ & $(0.011)^{\star \star}$ & $(0.010)$ & $(0.009)$ & $(0.007)$ & $(0.015)$ & $(0.012)^{*}$ & $(0.011)$ & $(0.009)$ & $(0.017)$ & $(0.015)$ & $(0.014)$ & $(0.012)$ & $(0.021)^{\star \star}$ & $(0.018)$ \\
\hline Boostrapped & $(0.007)^{* *}$ & $(0.006)$ & $(0.009)$ & $(0.009)$ & $(0.011)^{\star *}$ & $(0.010)$ & $(0.009)$ & $(0.007)$ & $(0.017)$ & $(0.012)^{*}$ & $(0.011)$ & $(0.009)$ & $(0.017)$ & $(0.015)$ & $(0.015)$ & $(0.012)$ & $(0.022)^{\star *}$ & $(0.018)$ \\
\hline$t=3(N$ & .009 & -0.006 & -0.006 & -0.005 & -0.021 & -0.016 & 0.004 & 0.00 & -0.020 & 0.012 & 0.006 & 0.000 & -0.010 & -0.007 & -0.001 & -0.006 & -0.051 & -0.035 \\
\hline Clustered & $(0.007)$ & $(0.007)$ & $(0.009)$ & $(0.009)$ & $(0.011)^{\star \star}$ & $(0.010)^{\star}$ & $(0.008)$ & $(0.006)$ & $(0.015)$ & $(0.013)$ & $(0.011)$ & $(0.008)$ & $(0.017)$ & $(0.016)$ & $(0.012)$ & $(0.012)$ & $(0.020)^{* *}$ & $(0.019)^{*}$ \\
\hline Boostrapped & $(0.007)$ & $(0.007)$ & $(0.010)$ & $(0.009)$ & $(0.011)^{\star \star}$ & $(0.010)^{*}$ & $(0.008)$ & $(0.006)$ & $(0.015)$ & $(0.014)$ & $(0.011)$ & $(0.008)$ & $(0.017)$ & $(0.017)$ & $(0.013)$ & $(0.011)$ & $(0.020)^{\star \star \star}$ & $(0.019)^{*}$ \\
\hline Observations & 227,619 & 232,725 & 141,272 & 143,347 & 84,051 & 87,044 & 114,582 & 114,967 & 113,037 & 113,457 & 70,881 & 71,085 & 70,391 & 70,626 & 42,565 & 42,724 & 41,486 & 41,655 \\
\hline Groups & & 72,933 & & 50,636 & & 34,344 & & 61,231 & & 60,666 & & 40,671 & & 40,339 & & 26,430 & & 26,152 \\
\hline
\end{tabular}

Source: Own calculations based on program evaluation surveys

Standard errors in parentheses.

Bootstrapped errors obtained by CRVE-Block Bootstrap with 300 replications.

* Significant at $10 \%$; ** significant at $5 \%$; *** significant at $1 \%$ 
Table 4

Program effects on agricultural employment, PRAF \& RPS

\begin{tabular}{|c|c|c|c|c|c|c|}
\hline & \multicolumn{6}{|c|}{ DD Estimates } \\
\hline & \multicolumn{2}{|c|}{ ITT } & \multicolumn{2}{|c|}{ ITT Males } & \multicolumn{2}{|c|}{ ITT Females } \\
\hline PRAF & OLS & FE & OLS & FE & OLS & FE \\
\hline \multicolumn{7}{|c|}{ Baseline: Aug-Dec. 2000} \\
\hline $\mathrm{t}=1$ (May-Aug. 2002) & -0.028 & -0.030 & -0.030 & -0.040 & -0.036 & 0.010 \\
\hline Clustered & $(0.039)$ & $(0.039)$ & $(0.041)$ & $(0.043)$ & $(0.057)$ & $(0.047)$ \\
\hline Boostrapped & $(0.038)$ & $(0.039)$ & $(0.042)$ & $(0.043)$ & $(0.058)$ & $(0.047)$ \\
\hline Observations & 8,158 & 7,931 & 6,451 & 6,257 & 1,707 & 1,674 \\
\hline Groups & & 5,034 & & 3,746 & & 1,289 \\
\hline
\end{tabular}

RPS

Baseline: Aug-Sept. 2000

\begin{tabular}{|c|c|c|c|c|c|c|}
\hline$t=1$ (Oct. 2001) & -0.002 & 0.017 & 0.001 & 0.014 & -0.004 & 0.041 \\
\hline Clustered & $(0.024)$ & $(0.020)$ & $(0.023)$ & $(0.020)$ & $(0.077)$ & $(0.078)$ \\
\hline Boostrapped & $(0.023)$ & $(0.020)$ & $(0.023)$ & $(0.020)$ & $(0.077)$ & $(0.077)$ \\
\hline $\mathrm{t}=2$ (Oct. 2002) & -0.013 & 0.016 & -0.002 & 0.010 & -0.037 & 0.083 \\
\hline Clustered & $(0.022)$ & $(0.019)$ & $(0.020)$ & $(0.019)$ & $(0.066)$ & $(0.063)$ \\
\hline Boostrapped & $(0.022)$ & $(0.020)$ & $(0.019)$ & $(0.021)$ & $(0.069)$ & $(0.061)$ \\
\hline Observations & 6,438 & 6,464 & 5,484 & 5,505 & 954 & 959 \\
\hline Groups & & 2,903 & & 2,239 & & 664 \\
\hline
\end{tabular}

Source: Own calculations based on program evaluation surveys

Standard errors in parentheses.

Bootstrapped errors obtained by CRVE-Block Bootstrap with 300 replications.

* Significant at $10 \%$; ** significant at 5\%; *** significant at $1 \%$ 
Table 5

Program effect on agricultural employment, PROGRESA

\begin{tabular}{|c|c|c|c|c|c|c|c|c|c|c|c|c|c|c|c|c|c|c|}
\hline \multirow{3}{*}{$\begin{array}{l}\text { PROGRESA } \\
\text { Baseline: Sept. 97-Mar. } 98\end{array}$} & \multicolumn{18}{|c|}{ DD Estimates } \\
\hline & \multicolumn{2}{|c|}{ ITT } & \multicolumn{2}{|c|}{ ATE } & \multicolumn{2}{|c|}{ ITE } & \multicolumn{2}{|c|}{ ITT Males } & \multicolumn{2}{|c|}{ ITT Females } & \multicolumn{2}{|c|}{ ATE Males } & \multicolumn{2}{|c|}{ ATE Females } & \multicolumn{2}{|c|}{ ITE Males } & \multicolumn{2}{|c|}{ ITE Females } \\
\hline & OLS & $\mathrm{FE}$ & OLS & $\mathrm{FE}$ & OLS & $\mathrm{FE}$ & OLS & FE & OLS & $\mathrm{FE}$ & OLS & FE & OLS & FE & OLS & $\mathrm{FE}$ & OLS & $\mathrm{FE}$ \\
\hline $\mathrm{t}=1$ (Nov. 98) & -0.010 & -0.007 & -0.015 & -0.010 & -0.004 & 0.000 & -0.014 & -0.016 & -0.029 & -0.034 & -0.017 & -0.013 & -0.058 & -0.040 & -0.012 & -0.017 & -0.006 & -0.040 \\
\hline Clustered & $(0.012)$ & $(0.010)$ & $(0.011)$ & $(0.011)$ & $(0.016)$ & $(0.016)$ & $(0.012)$ & $(0.012)$ & $(0.035)$ & $(0.030)$ & $(0.013)$ & $(0.013)$ & $(0.046)$ & $(0.059)$ & $(0.018)$ & $(0.021)$ & $(0.037)$ & $(0.042)$ \\
\hline Boostrapped & $(0.012)$ & $(0.010)$ & $(0.012)$ & $(0.011)$ & $(0.017)$ & $(0.016)$ & $(0.013)$ & $(0.012)$ & $(0.033)$ & $(0.029)$ & $(0.012)$ & $(0.014)$ & $(0.047)$ & $(0.059)$ & $(0.017)$ & $(0.020)$ & $(0.040)$ & $(0.039)$ \\
\hline $\mathrm{t}=2$ (Mar. 99) & -0.007 & -0.001 & -0.009 & -0.004 & 0.011 & 0.029 & -0.011 & -0.006 & -0.024 & -0.028 & -0.016 & -0.012 & -0.046 & -0.041 & 0.014 & 0.044 & 0.008 & -0.034 \\
\hline Clustered & $(0.011)$ & $(0.010)$ & $(0.012)$ & $(0.011)$ & $(0.020)$ & $(0.020)$ & $(0.012)$ & $(0.013)$ & $(0.034)$ & $(0.032)$ & $(0.013)$ & $(0.013)$ & $(0.046)$ & $(0.059)$ & $(0.024)$ & $(0.026)^{\star}$ & $(0.039)$ & $(0.048)$ \\
\hline Boostrapped & $(0.011)$ & $(0.011)$ & $(0.012)$ & $(0.011)$ & $(0.019)$ & $(0.020)$ & $(0.012)$ & $(0.012)$ & $(0.033)$ & $(0.031)$ & $(0.013)$ & $(0.014)$ & $(0.046)$ & $(0.061)$ & $(0.024)$ & $(0.028)$ & $(0.039)$ & $(0.049)$ \\
\hline $\mathrm{t}=3$ (Nov. 99) & 0.004 & 0.003 & 0.006 & 0.001 & 0.004 & 0.019 & 0.019 & 0.006 & -0.036 & -0.027 & 0.020 & -0.003 & -0.051 & -0.037 & 0.024 & 0.037 & -0.027 & -0.050 \\
\hline Clustered & $(0.012)$ & $(0.011)$ & $(0.012)$ & $(0.012)$ & $(0.020)$ & $(0.021)$ & $(0.013)$ & $(0.014)$ & $(0.034)$ & $(0.032)$ & $(0.013)$ & $(0.016)$ & $(0.047)$ & $(0.058)$ & $(0.023)$ & $(0.026)$ & $(0.038)$ & $(0.046)$ \\
\hline Boostrapped & $(0.013)$ & $(0.010)$ & $(0.012)$ & $(0.012)$ & $(0.021)$ & $(0.021)$ & $(0.012)$ & $(0.014)$ & $(0.033)$ & $(0.031)$ & $(0.013)$ & $(0.016)$ & $(0.047)$ & $(0.060)$ & $(0.023)$ & $(0.028)$ & $(0.038)$ & $(0.046)$ \\
\hline Observations & 84,210 & 86,176 & 52,977 & 53,775 & 30,209 & 31,364 & 51,062 & 51,212 & 33,148 & 33,267 & 31,578 & 31,646 & 21,399 & 21,457 & 18,882 & 18,956 & 11,327 & 11,383 \\
\hline Groups & & 38,583 & & 25,200 & & 17,534 & & 30,349 & & 24,673 & & 19,281 & & 16,091 & & 13,259 & & 9,340 \\
\hline
\end{tabular}

Source: Own calculations based on program evaluation surveys

Standard errors in parentheses.

Bootstrapped errors obtained by CRVE-Block Bootstrap with 300 replications.

* Significant at $10 \%$; ** significant at $5 \%$; *** significant at $1 \%$ 
Table 6

Program effects on individual hours of work, PRAF \& RPS

\section{DD Estimates}

\begin{tabular}{|c|c|c|c|c|c|c|}
\hline \multirow{4}{*}{$\begin{array}{l}\text { PRAF } \\
\text { Baseline: Aug-Dec. } 2000\end{array}$} & \multirow{2}{*}{\multicolumn{2}{|c|}{ ITT }} & \multirow{2}{*}{\multicolumn{2}{|c|}{$\begin{array}{l}\text { DD Estimates } \\
\text { ITT Males }\end{array}$}} & \multirow{2}{*}{\multicolumn{2}{|c|}{ ITT Females }} \\
\hline & & & & & & \\
\hline & OLS & FE & OLS & $\mathrm{FE}$ & OLS & $\mathrm{FE}$ \\
\hline & & & & & & \\
\hline t=1 (May-Aug. 2002) & 0.681 & 0.814 & 0.493 & 0.580 & 1.840 & 1.849 \\
\hline Clustered & $(0.642)$ & $(0.650)$ & $(0.620)$ & $(0.617)$ & $(1.319)$ & $(1.716)$ \\
\hline Boostrapped & $(0.657)$ & $(0.631)$ & $(0.569)$ & $(0.676)$ & $(1.400)$ & (1.789) \\
\hline Observations & 8,139 & 7,913 & 6,438 & 6,245 & 1,701 & 1,668 \\
\hline Groups & & 5,029 & & 3,745 & & 1,285 \\
\hline
\end{tabular}

RPS

Baseline: Aug-Sept. 2000

\begin{tabular}{|c|c|c|c|c|c|c|}
\hline $\mathrm{t}=1$ (Oct. 2001) & -2.638 & -2.982 & -2.261 & -2.667 & -3.030 & -4.067 \\
\hline Clustered & $(1.841)$ & $(1.807)$ & $(1.614)$ & $(1.649)$ & $(4.390)$ & $(4.734)$ \\
\hline Boostrapped & $(1.830)$ & $(1.814)$ & (1.609) & $(1.678)$ & $(4.416)$ & $(4.601)$ \\
\hline $\mathrm{t}=2$ (Oct. 2002) & -1.996 & -1.971 & -1.475 & -1.672 & -5.668 & -4.001 \\
\hline Clustered & $(1.884)$ & $(1.882)$ & $(1.792)$ & $(1.798)$ & $(4.039)$ & $(4.584)$ \\
\hline Boostrapped & $(1.885)$ & $(1.890)$ & $(1.868)$ & $(1.869)$ & (3.929) & $(4.584)$ \\
\hline Observations & 6,634 & 6,660 & 5,503 & 5,524 & 1,131 & 1,136 \\
\hline Groups & & 3,021 & & 2,245 & & 776 \\
\hline
\end{tabular}

Source: Own calculations based on program evaluation surveys

Standard errors in parentheses.

Bootstrapped errors obtained by CRVE-Block Bootstrap with 300 replications.

* Significant at 10\%; ** significant at 5\%; *** significant at $1 \%$ 
Table 7

Program effect on individual hours of work, PROGRESA

\begin{tabular}{|c|c|c|c|c|c|c|c|c|c|c|c|c|c|c|c|c|c|c|}
\hline \multirow{3}{*}{$\begin{array}{l}\text { PROGRESA } \\
\text { Baseline: Sept. 97-Mar. } 98\end{array}$} & \multicolumn{18}{|c|}{ DD Estimates } \\
\hline & \multicolumn{2}{|c|}{ ITT } & \multicolumn{2}{|c|}{ ATE } & \multicolumn{2}{|c|}{ ITE } & \multicolumn{2}{|c|}{ ITT Males } & \multicolumn{2}{|c|}{ ITT Females } & \multicolumn{2}{|c|}{ ATE Males } & \multicolumn{2}{|c|}{ ATE Females } & \multicolumn{2}{|c|}{ ITE Males } & \multicolumn{2}{|c|}{ ITE Females } \\
\hline & OLS & $\mathrm{FE}$ & OLS & $\mathrm{FE}$ & OLS & $\mathrm{FE}$ & OLS & $\mathrm{FE}$ & OLS & $\mathrm{FE}$ & OLS & $\mathrm{FE}$ & OLS & $\mathrm{FE}$ & OLS & $\mathrm{FE}$ & OLS & $\mathrm{FE}$ \\
\hline$=1$ (Nov. 98) & 0.616 & 0.648 & 0.834 & 0.521 & 0.285 & 0.648 & 0.659 & 1.100 & 0.686 & 1.203 & 0.608 & 0.708 & 2.144 & 0.407 & 0.708 & 1.196 & -0.642 & 1.718 \\
\hline Clustered & $(0.578)$ & $(0.578)$ & $(0.684)$ & $(0.703)$ & $(0.670)$ & $(0.663)$ & $(0.607)$ & $(0.619)^{*}$ & $(0.884)$ & $(1.500)$ & $(0.722)$ & $(0.733)$ & (1.368) & (2.497) & $(0.726)$ & $(0.775)$ & (1.070) & (2.035) \\
\hline Boostrapped & (0.572) & (0.542) & $(0.704)$ & $(0.706)$ & $(0.671)$ & $(0.668)$ & (0.614) & $(0.625)^{*}$ & $(0.865)$ & (1.584) & $(0.707)$ & $(0.805)$ & (1.332) & (2.671) & $(0.711)$ & $(0.755)$ & (1.057) & (2.006) \\
\hline $\mathrm{t}=3$ (Nov. 99) & 0.085 & 0.258 & 0.173 & 0.010 & -0.422 & 0.157 & -0.172 & 0.178 & 0.457 & 1.06 & -0.102 & -0.395 & 1.418 & -0.201 & -0.688 & -0.418 & -0.450 & 2.849 \\
\hline Clustered & $(0.576)$ & $(0.566)$ & (0.673) & $(0.719)$ & $(0.771)$ & $(0.802)$ & $(0.631)$ & $(0.640)$ & $(0.871)$ & (1.486) & $(0.723)$ & $(0.793)$ & (1.392) & (2.503) & $(0.858)$ & $(1.016)$ & (1.142) & (2.151) \\
\hline Boostrapped & $(0.560)$ & $(0.581)$ & (0.729) & $(0.694)$ & $(0.797)$ & (0.802) & $(0.675)$ & $(0.680)$ & $(0.859)$ & (1.572) & $(0.714)$ & $(0.760)$ & (1.401) & (2.651) & (0.853) & (1.025) & (1.154) & (2.148) \\
\hline Observations & 78,020 & 79,832 & 43,996 & 44,720 & 33,138 & 34,216 & 50,373 & 50,483 & 27,647 & 27,742 & 27,888 & 27,933 & 16,108 & 16,150 & 22,007 & 22,066 & 11,131 & 11,180 \\
\hline Groups & & 41,799 & & 24,959 & & 20,653 & & 33,227 & & 23,661 & & 18,848 & & 13,977 & & 16,184 & & 10,029 \\
\hline
\end{tabular}

Source: Own calculations based on program evaluation surveys

Standard errors in parentheses.

Bootstrapped errors obtained by CRVE-Block Bootstrap with 300 replications.

* Significant at $10 \%$; ** significant at 5\%; *** significant at $1 \%$ 
Table 8

Program effects on hours worked by adults in the household, PRAF \& RPS

\begin{tabular}{|c|c|c|c|c|c|c|}
\hline \multirow[b]{3}{*}{ PRAF } & \multicolumn{6}{|c|}{ DD Estimates } \\
\hline & \multicolumn{2}{|c|}{ ITT } & \multicolumn{2}{|c|}{ ITT Males } & \multicolumn{2}{|c|}{ ITT Females } \\
\hline & OLS & $\mathrm{FE}$ & OLS & $\mathrm{FE}$ & OLS & $\mathrm{FE}$ \\
\hline \multicolumn{7}{|l|}{ Baseline: Aug-Dec. 2000} \\
\hline $\mathrm{t}=1$ (May-Aug. 2002) & 0.644 & 1.148 & 0.516 & 0.654 & 2.677 & 2.583 \\
\hline Clustered & $(1.567)$ & $(1.506)$ & $(1.719)$ & $(1.801)$ & $(3.436)$ & $(4.029)$ \\
\hline Boostrapped & (1.633) & $(1.468)$ & $(1.638)$ & $(1.817)$ & (3.514) & $(4.174)$ \\
\hline Observations & 5,344 & 5,344 & 4,537 & 4,537 & 807 & 807 \\
\hline Groups & & 2,999 & & 2,540 & & 525 \\
\hline
\end{tabular}

RPS

Baseline: Aug-Sept. 2000

\begin{tabular}{|c|c|c|c|c|c|c|}
\hline$t=1$ (Oct. 2001) & -4.444 & -5.174 & -3.447 & -4.356 & -12.338 & -10.627 \\
\hline Clustered & $(2.911)$ & $(2.787)^{\star}$ & $(2.873)$ & $(2.861)$ & $(7.767)$ & (8.151) \\
\hline Boostrapped & $(2.977)$ & $(2.962)^{\star}$ & $(2.706)$ & $(2.606)^{\star}$ & $(7.308)^{\star}$ & $(7.974)$ \\
\hline$t=2$ (Oct. 2002) & -4.769 & -6.380 & -3.546 & -5.211 & -16.023 & -14.832 \\
\hline Clustered & $(2.809)^{\star}$ & $(2.904)^{\star \star}$ & $(2.831)$ & $(2.899)^{\star}$ & $(6.267)^{\star *}$ & $(6.896)^{\star \star}$ \\
\hline Boostrapped & $(2.978)$ & $(2.831)^{\star \star}$ & (2.687) & $(2.926)^{*}$ & $(6.513)^{\star *}$ & $(6.855)^{\star \star}$ \\
\hline Observations & 4,124 & 4,124 & 3,652 & 3,652 & 472 & 472 \\
\hline Groups & & 1,525 & & 1,331 & & 194 \\
\hline
\end{tabular}

Source: Own calculations based on program evaluation surveys

Standard errors in parentheses.

Bootstrapped errors obtained by CRVE-Block Bootstrap with 300 replications.

* Significant at $10 \%$; ** significant at 5\%; *** significant at $1 \%$ 
Table 9

Program effect on hours worked by adults in the household, PROGRESA

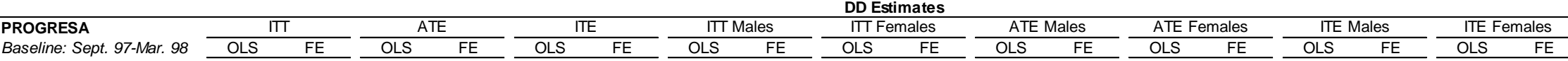

Clustered

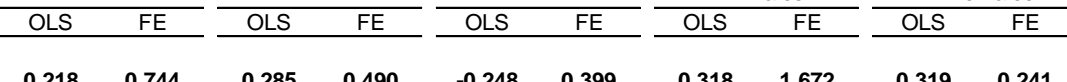
ITE Females
OLS FE

Boostrapped

$\begin{array}{llllllllll}0.218 & 0.744 & 0.285 & 0.490 & -0.248 & 0.399 & 0.318 & 1.672 & 0.319 & 0.241\end{array}$

$0.688 \quad 0.298$

$-0.976 \quad-4.544$

$1.158 \quad 4.588$

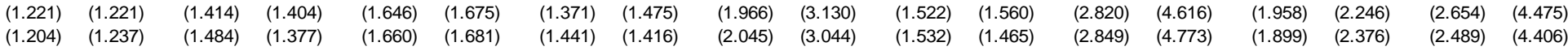

$t=3$ (Nov. 99)

Clustered

Boostrapped

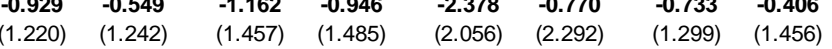

$-0.850 \quad-1.722$

$-0.866 \quad-0.883$

$\begin{array}{llllll}-2.475 & -8.076 & -2.378 & -1.798 & -0.285 & 7.463\end{array}$

Observations

(1.241)

$\begin{array}{llllll}(1.488) & (1.444) & (2.095) & (2.375) & (1.367) & (1.415)\end{array}$

\begin{tabular}{ll}
$(2.067)$ & $(3.189)$ \\
\hline
\end{tabular}

$(1.589) \quad(1.627)$

\begin{tabular}{ll}
$(2.817)$ & $(5.021)$ \\
\hline
\end{tabular}

\begin{tabular}{llll}
$(2.375)$ & $(3.011)$ & $(3.433)$ & $(5.268)$ \\
$(2.375)$ & $(3.071)$ & $(3.010)$ & $(5.091)$ \\
\hline
\end{tabular}

34,775

21,580

37,513
22,937 $\frac{18,460 \quad 18,460}{14,700}$

22,359

$\frac{11,895}{9,776}$

14,717
10,110

Source: Own calculations based on program evaluation surveys

Standard errors in parentheses.

Bootstrapped errors obtained by CRVE-Block Bootstrap with 300 replications.

* Significant at $10 \%$; * significant at $5 \%$; *** significant at $1 \%$ 
Table 10

Program effect on individual log hourly wages, PROGRESA

\begin{tabular}{|c|c|c|c|c|c|c|c|c|c|c|c|c|c|c|c|c|c|c|}
\hline \multirow{3}{*}{$\begin{array}{l}\text { PROGRESA } \\
\text { Baseline: Sept. 97-Mar. } 98\end{array}$} & \multicolumn{18}{|c|}{ DD Estimates } \\
\hline & \multicolumn{2}{|c|}{ ITT } & \multicolumn{2}{|c|}{ ATE } & \multicolumn{2}{|c|}{ ITE } & \multicolumn{2}{|c|}{ ITT Males } & \multicolumn{2}{|c|}{ ITT Females } & \multicolumn{2}{|c|}{ ATE Males } & \multicolumn{2}{|c|}{ ATE Females } & \multicolumn{2}{|c|}{ ITE Males } & \multicolumn{2}{|c|}{ ITE Females } \\
\hline & OLS & $\mathrm{FE}$ & OLS & $\mathrm{FE}$ & OLS & $\mathrm{FE}$ & OLS & $\mathrm{FE}$ & OLS & $\mathrm{FE}$ & OLS & $\mathrm{FE}$ & OLS & $\mathrm{FE}$ & OLS & $\mathrm{FE}$ & OLS & $\mathrm{FE}$ \\
\hline $\mathrm{t}=1$ (Nov. 98 ) & 0.011 & 0.015 & -0.005 & 0.007 & 0.030 & 0.024 & 0.007 & 0.013 & -0.024 & -0.071 & -0.002 & 0.007 & -0.100 & -0.034 & 0.020 & 0.030 & 0.036 & -0.088 \\
\hline Clustered & $(0.032)$ & $(0.030)$ & $(0.040)$ & $(0.034)$ & $(0.036)$ & $(0.039)$ & $(0.031)$ & $(0.033)$ & $(0.088)$ & $(0.076)$ & $(0.037)$ & $(0.041)$ & $(0.161)$ & $(0.132)$ & $(0.039)$ & $(0.042)$ & $(0.073)$ & $(0.109)$ \\
\hline Boostrapped & $(0.032)$ & $(0.029)$ & $(0.041)$ & $(0.033)$ & $(0.035)$ & $(0.037)$ & $(0.031)$ & $(0.033)$ & $(0.084)$ & $(0.077)$ & $(0.037)$ & $(0.040)$ & (0.153) & $(0.130)$ & $(0.039)$ & $(0.042)$ & $(0.070)$ & $(0.109)$ \\
\hline $\mathrm{t}=3$ (Nov. 99) & 0.051 & 0.057 & 0.050 & 0.069 & 0.052 & 0.036 & 0.057 & 0.06 & 0.00 & -0.056 & 0.054 & 0.082 & -0.052 & 0.008 & 0.062 & 0.056 & 0.026 & -0.110 \\
\hline Clustered & $(0.033)$ & $(0.030)^{*}$ & $(0.039)$ & $(0.035)^{\star *}$ & $(0.039)$ & $(0.040)$ & $(0.031)^{\star}$ & $(0.034)^{\star}$ & $(0.090)$ & $(0.076)$ & $(0.034)$ & $(0.042)^{*}$ & $(0.161)$ & $(0.136)$ & $(0.041)$ & $(0.053)$ & $(0.073)$ & $(0.114)$ \\
\hline Boostrapped & $(0.036)$ & $(0.029)^{\star}$ & $(0.038)$ & $(0.035)^{* *}$ & $(0.041)$ & $(0.040)$ & $(0.030)^{*}$ & $(0.033)^{* \star}$ & $(0.086)$ & $(0.074)$ & $(0.036)$ & $(0.042)^{*}$ & $(0.151)$ & $(0.133)$ & $(0.041)$ & $(0.055)$ & $(0.074)$ & $(0.117)$ \\
\hline Observations & 71,536 & 73,316 & 41,258 & 41,977 & 29,401 & 30,453 & 46,124 & 46,228 & 25,412 & 25,502 & 26,129 & 26,174 & 15,129 & 15,170 & 19,521 & 19,575 & 9,880 & 9,925 \\
\hline Groups & & 38,917 & & 23,740 & & 18,704 & & 30,835 & & 21,678 & & 17,914 & & 13,099 & & 14,559 & & 8,894 \\
\hline
\end{tabular}

Source: Own calculations based on program evaluation surveys

Standard errors in parentheses.

Bootstrapped errors obtained by CRVE-Block Bootstrap with 300 replications.

* Significant at $10 \%$; * significant at $5 \%$; *** significant at $1 \%$

\section{Table 11}

Program effect on log household labor income per adult, PROGRESA

\begin{tabular}{|c|c|c|c|c|c|c|c|c|c|c|c|c|c|c|c|c|c|c|}
\hline \multirow{3}{*}{$\begin{array}{l}\text { PROGRESA } \\
\text { Baseline: Sept. 97-Mar. } 98\end{array}$} & \multicolumn{18}{|c|}{ D Estimates } \\
\hline & \multicolumn{2}{|c|}{$1 \pi T$} & \multicolumn{2}{|c|}{ ATE } & \multicolumn{2}{|c|}{ ITE } & \multicolumn{2}{|c|}{ ITT Males } & \multicolumn{2}{|c|}{ ITT Females } & \multicolumn{2}{|c|}{ ATE Males } & \multicolumn{2}{|c|}{ ATE Females } & \multicolumn{2}{|c|}{ ITE Males } & \multicolumn{2}{|c|}{ ITE Females } \\
\hline & OLS & $\mathrm{FE}$ & OLS & $\mathrm{FE}$ & OLS & $\mathrm{FE}$ & OLS & $\mathrm{FE}$ & $\mathrm{OLS}$ & $\mathrm{FE}$ & OLS & $\mathrm{FE}$ & OLS & $\mathrm{FE}$ & OLS & $\mathrm{FE}$ & OLS & $\mathrm{FE}$ \\
\hline$=1$ (Nov. 98) & 0.020 & 0.036 & 0.015 & 0.029 & 0.025 & 0.047 & 0.008 & 0.021 & 0.025 & 0.139 & 0.011 & 0.025 & -0.014 & 0.077 & 0.009 & 0.015 & 0.077 & 0.176 \\
\hline Clustered & $(0.026)$ & $(0.025)$ & $(0.027)$ & $(0.027)$ & $(0.035)$ & $(0.035)$ & $(0.027)$ & $(0.029)$ & $(0.060)$ & $(0.077)^{\star}$ & $(0.028)$ & $(0.031)$ & $(0.081)$ & (0.114) & $(0.040)$ & $(0.044)$ & $(0.081)$ & $(0.114)$ \\
\hline Boostrapped & $(0.027)$ & $(0.026)$ & $(0.026)$ & $(0.026)$ & $(0.032)$ & $(0.034)$ & $(0.028)$ & $(0.030)$ & $(0.059)$ & $(0.078)^{*}$ & $(0.027)$ & $(0.031)$ & $(0.081)$ & (0.114) & $(0.039)$ & $(0.043)$ & $(0.081)$ & $(0.123)$ \\
\hline$t=2(1$ & 0.017 & 0.027 & 0.008 & 0.021 & 0.027 & 0.048 & 0.033 & 0.032 & $-0 . c$ & 0.108 & 0.028 & 0.038 & -0.050 & 0.084 & 0.049 & 0.034 & 0.044 & 0.096 \\
\hline Cluste & $(0.027)$ & $(0.027)$ & $(0.030)$ & $(0.030)$ & $(0.039)$ & $(0.042)$ & $(0.029)$ & $(0.030)$ & $(0.061)$ & $(0.080)$ & $(0.032)$ & $(0.035)$ & $(0.084)$ & (0.119) & $(0.047)$ & $(0.055)$ & $(0.083)$ & $(0.123)$ \\
\hline Boostrapped & $(0.029)$ & $(0.027)$ & $(0.030)$ & $(0.029)$ & $(0.037)$ & $(0.039)$ & $(0.029)$ & $(0.031)$ & $(0.063)$ & $(0.084)$ & $(0.032)$ & $(0.035)$ & $(0.084)$ & $(0.116)$ & $(0.043)$ & $(0.058)$ & $(0.076)$ & $(0.135)$ \\
\hline $\mathrm{t}=3$ (Nov. 99) & 0.053 & 0.068 & 0.051 & 0.074 & 0.044 & 0.04 & 0.057 & 0.06 & 0.0 & 0.1 & 0.055 & 0.0 & 0.0 & 0.116 & 0.030 & 0.0 & 0.099 & 0.132 \\
\hline Cluste & $(0.029)^{*}$ & $(0.029)^{\star \star}$ & $(0.032)$ & $(0.032)^{\star \star}$ & $(0.044)$ & $(0.0$ & $(0.030)^{\star}$ & $(0.03$ & $(0.0$ & $(0.0$ & $(0.033)^{*}$ & $(0.0$ & $(0.084)$ & $(0.117)$ & $(0.049)$ & $(0.059)$ & $(0.084)$ & $(0.120)$ \\
\hline Boostrapped & $(0.032)^{*}$ & $(0.031)^{* \star}$ & $(0.029)^{\star}$ & $(0.031)^{* \star}$ & $(0.042)$ & $(0.046)$ & $(0.030)^{\star}$ & $(0.030)^{* \star}$ & $(0.059)$ & $(0.080)^{*}$ & $(0.034)$ & $(0.036)^{* \star}$ & $(0.085)$ & $(0.117)$ & $(0.048)$ & $(0.057)$ & $(0.079)$ & $(0.131)$ \\
\hline Dsservat & 66,209 & 67,369 & 43,591 & 44,114 & 21,713 & 22,350 & 42,194 & 42,194 & 24,015 & 24,015 & 26,903 & 26,903 & 16,688 & 16,688 & 14,766 & 14,766 & 6,947 & 6,947 \\
\hline Groups & & 24,865 & & 17,502 & & 10,762 & & 22,539 & & 16,584 & & 14,933 & & 11,766 & & 9,618 & & 5,419 \\
\hline
\end{tabular}
24,865 17,502

Standard errors in parentheses. Bootstrapped errors obtained by CRVE-Block Bootstrap with 300 replications. * Significant at $10 \%$; ** significant at $5 \%$; *** significant at $1 \%$ 


\section{Appendix: Brief description of the programs \\ Mexico: PROGRESA Program}

In 1997, Mexico began implementing the first phase of the PROGRESA conditional cash transfer (later renamed Oportunidades) in rural areas. The program had a multi-sector focus, with intended impacts on education, health and nutrition, besides the potential for poverty alleviation from the cash transfer.

The initial deployment of the program was designed to facilitate the evaluation of its impact. The program was geographically targeted by locality, based on a poverty index. From an initial group of 506 localities selected for the first round, 320 were randomly selected to participate in the PROGRESA program (i.e., qualifying households in those localities would be eligible to participate), while the program was not deployed in the remaining 186 localities. Households in the latter localities were still subject to the data collection process, and thus constituted the control group for the program's evaluation. ${ }^{16}$ Although the program was later expanded to cover additional areas, this document uses the initial 1997-1999 period.

The data employed in this study originates in the PROGRESA Evaluation Survey (ENCEL-Encuesta de Evaluación de los Hogares). The estimates shown in the paper are based on the initial baseline survey, and three follow-up rounds implemented in the subsequent semesters after the program's implementation. The surveys collected socio-demographic and labor market information at the household and individual levels for the treatment and control localities - in fact, the surveys interviewed all households in these localities.

\section{Honduras: PRAF Program}

The Programa de Asignación Familiar (PRAF) was created by the Government of Honduras in the early 1990s as a compensatory mechanism to mitigate the impact of macroeconomic adjustments on the poor and alleviate structural poverty. Through several expansion phases, it reached a target population of 173,000 households with children from 0 to 14 years old in 2008, and it constitutes one of the largest welfare programs in the country. The objective of the program is to encourage

\footnotetext{
${ }^{16}$ The evaluation followed a phase-in process: PROGRESA was deployed in the control localities when the program expanded its coverage in 2000.
} 
poor households to invest in human capital -primarily education and health- through conditional cash transfers.

This study concentrates on the second phase of the program (PRAF II), a reorganization of the original intervention planned in the late 1990s (Glewwe and Olinto, 2004). This PRAF II (PRAF for short) ${ }^{17}$ was implemented in 2000, and geographically targeted at the municipality level in the poorest region of the country (IFPRI, 2000). It was deployed in a set of 50 randomly selected municipalities of a total of 70 , with the 20 additional municipalities forming the control group. While the experimental design of PROGRESA attempted to study the overall impact of the program, the PRAF design was more ambitious. The evaluation originally intended to contrast different types of interventions, and thus three sub-groups were created within the treatment group: (i) municipalities scheduled to receive a demand-side intervention (cash subsidies), (ii) those scheduled to receive a supply-side intervention (i.e., construction of schools and health centers), and (iii) a group that would receive both. The empirical results presented below are based on the control group and the municipalities in the first treatment sub-group, since the supply-side interventions were never implemented (Glewwe and Olinto, 2004) and there are a reduced number of municipalities in the combined intervention group. ${ }^{18}$ The number of municipalities used in the estimation is 40, with 20 in which eligible households could participate in PRAF and 20 in which the program was not deployed.

The data in this document corresponds to a baseline survey carried out in the last quarter of 2000 and a follow-up survey in 2002, with a reasonably low sample attrition of approximately 8 percent. In contrast to the case of PROGRESA, where all households in treatment and control localities were interviewed, the PRAF surveys covered a sample of households. The corresponding sampling weights are used when possible in the empirical work below.

\section{Nicaragua: RPS Program}

The Red de Protección Social (RPS) conditional cash transfer program started in 2000. A first phase consisted of a three-year pilot in two rural areas of the central

\footnotetext{
${ }^{17}$ This phase was followed by a new one, which was implemented by the Government at the time that this report was prepared in 2008-2009.

${ }^{18}$ For more on this, see Glewwe and Olinto (2004).
} 
region of Nicaragua (Madriz and Matagalpa), with poverty rates above the national average. The program was broadly modeled after PROGRESA, and its main objective was to improve households' human capital through conditional cash transfers.

The 42 localities ("comarcas") with the lowest levels of a multidimensional marginality index within the intervention area were selected for the pilot. Half of those localities were randomly assigned to the treatment group, and the other half to the control group (Maluccio and Flores, 2005). The program was originally scheduled to be deployed in the control group localities after a year, but a series of delays meant that they were only incorporated two years later.

The data used in this document corresponds to the initial baseline survey carried out in the third quarter of 2000, and the first follow-up survey conducted in 2001. The sample attrition rate is approximately 7 percent. As with the PRAF evaluation data, the survey consists of a sample of the targeted population, and sampling weights are used when possible. 


\section{Appendix: Analysis of the random assignment process}

Tables A1-A3 present the results of a probit regression of the probability of being selected into the treatment sample for each program as a function of observable household and individual characteristics. Since the focus of this document is to estimate differentiated treatment effects across population subgroups, estimates are presented for the entire adult population aged 15-65, and separately by gender, with standard errors clustered at the locality level. ${ }^{19}$ The results reveal some significant differences between treatment and control groups in all three programs.

The results from PRAF indicate that treatment and control localities varied in two important dimensions. Households in the treatment sample had a significantly higher proportion of children attending school, and a significantly lower proportion of children employed. There do not seem to be any significant differences by gender.

In localities selected for PROGRESA deployment, there was a significantly higher proportion of individuals employed, and this effect was accounted for mainly by men. The treatment and control samples from RPS, according to the probit regression, seem to be more balanced. None of the included variables is significantly associated with the probability of participation in the program.

\footnotetext{
${ }^{19}$ A number of other models were estimated using further disaggregated characteristics. However, the results were qualitatively similar. Some of the differences disappear once the probit regression accounts for clustering at the locality level.
} 
Table A1-Probit estimates for treatment (marginal effects), baseline year, PRAF

\begin{tabular}{|c|c|c|c|}
\hline Variable & All & Men & Women \\
\hline Age & $\begin{array}{l}0.0006 \\
(0.001)\end{array}$ & $\begin{array}{l}0.0011 \\
(0.001)\end{array}$ & $\begin{array}{l}0.0005 \\
(0.001)\end{array}$ \\
\hline Gender $(1=$ Male, $0=$ Female $)$ & $\begin{array}{l}0.0302 \\
(0.028)\end{array}$ & & \\
\hline Number of children & $\begin{array}{l}0.0021 \\
(0.009)\end{array}$ & $\begin{array}{l}0.0001 \\
(0.009)\end{array}$ & $\begin{array}{l}0.0028 \\
(0.009)\end{array}$ \\
\hline Children employed & $\begin{array}{c}-0.0865 \\
(0.0270)^{\star * \star}\end{array}$ & $\begin{array}{c}-0.0930 \\
(0.0297)^{\star \star *}\end{array}$ & $\begin{array}{c}-0.0813 \\
(0.0284)^{\star \star \star}\end{array}$ \\
\hline Children attending school & $\begin{array}{c}0.1032 \\
(0.0375)^{\star \star \star}\end{array}$ & $\begin{array}{c}0.1249 \\
(0.0371)^{\star \star \star}\end{array}$ & $\begin{array}{c}0.0909 \\
(0.0400)^{\star *}\end{array}$ \\
\hline Literacy $(1=$ Yes, $0=$ No) & $\begin{array}{l}0.0019 \\
(0.036)\end{array}$ & $\begin{array}{l}0.0372 \\
(0.034)\end{array}$ & $\begin{array}{l}-0.0216 \\
(0.045)\end{array}$ \\
\hline Employed $(1=$ Yes, $0=$ No) & $\begin{array}{c}-0.0109 \\
(0.035)\end{array}$ & $\begin{array}{r}-0.0450 \\
(0.046)\end{array}$ & $\begin{array}{l}0.0427 \\
(0.038)\end{array}$ \\
\hline $\begin{array}{l}\text { Observations } \\
\text { LR Chi2 }\end{array}$ & $\begin{array}{l}6,897 \\
30.62\end{array}$ & $\begin{array}{l}2,868 \\
30.65\end{array}$ & $\begin{array}{l}4,029 \\
24.16\end{array}$ \\
\hline
\end{tabular}

Source: Own calculations based on program evaluation survey.

Standard errors in parentheses, clustered at the locality level.

* Significant at $10 \%$; ** significant at 5\%; *** significant at $1 \%$

Table A2-Probit estimates for treatment (marginal effects), baseline year, PROGRESA

\begin{tabular}{lccc}
\hline \multicolumn{1}{c}{ Variable } & All & Men & Women \\
\hline Age & -0.0001 & 0.0002 & -0.0003 \\
& $(0.000)$ & $(0.001)$ & $(0.000)$ \\
Gender (1 = Male, 0= Female) & -0.0155 & & \\
& $(0.011)$ & & \\
Number of children & 0.0038 & 0.0050 & 0.0032 \\
& $(0.004)$ & $(0.004)$ & $(0.004)$ \\
Children employed & -0.0113 & -0.0192 & -0.0067 \\
& $(0.012)$ & $(0.013)$ & $(0.012)$ \\
Children attending school & 0.0019 & 0.0039 & -0.0001 \\
& $(0.015)$ & $(0.016)$ & $(0.015)$ \\
Literacy (1= Yes, 0= No) & -0.0178 & -0.0089 & -0.0266 \\
Employed (1= Yes, 0= No) & $(0.026)$ & $(0.029)$ & $(0.025)$ \\
& 0.0311 & 0.0443 & 0.0160 \\
& $(0.0152)^{* *}$ & $(0.0216)^{* *}$ & $(0.016)$ \\
Observations & & & \\
LR Chi2 & 66,646 & 33,257 & 33,389 \\
Sol & 9.63 & 8.71 & 2.48
\end{tabular}

Source: Own calculations based on program evaluation survey.

Standard errors in parentheses, clustered at the locality level.

* Significant at 10\%; ** significant at 5\%; *** significant at $1 \%$

Table A3-Probit estimates for treatment (marginal effects), baseline year, RPS

\begin{tabular}{lccc}
\hline \multicolumn{1}{c}{ Variable } & All & Men & Women \\
\hline Age & -0.0001 & -0.0001 & -0.0001 \\
Gender (1 = Male, 0= Female) & $(0.001)$ & $(0.001)$ & $(0.001)$ \\
& 0.0217 & & \\
Number of children & $(0.028)$ & & \\
& -0.0010 & 0.0008 & -0.0029 \\
Children employed & $(0.012)$ & $(0.012)$ & $(0.012)$ \\
& -0.0509 & -0.0623 & -0.0390 \\
Children attending school & $(0.038)$ & $(0.041)$ & $(0.038)$ \\
& 0.0349 & 0.0322 & 0.0388 \\
Literacy (1= Yes, 0= No) & $(0.044)$ & $(0.044)$ & $(0.046)$ \\
& 0.0152 & 0.0118 & 0.0191 \\
Employed (1= Yes, 0= No) & $(0.033)$ & $(0.043)$ & $(0.032)$ \\
& -0.0188 & -0.0292 & 0.0068 \\
& $(0.035)$ & $(0.046)$ & $(0.049)$ \\
Observations & & & \\
LR Chi2 & 4,674 & 2,290 & 2,384 \\
SOurce: OWn & 3.96 & 3.8 & 2.31 \\
\hline
\end{tabular}

Source: Own calculations based on program evaluation survey.

Standard errors in parentheses, clustered at the locality level.

* Significant at $10 \%$; * significant at 5\%; *** significant at $1 \%$ 


\section{SERIE DOCUMENTOS DE TRABAJO DEL CEDLAS}

Todos los Documentos de Trabajo del CEDLAS están disponibles en formato electrónico en 〈www.depeco.econo.unlp.edu.ar/cedlas〉.

- Nro. 95 (Marzo, 2010). María Laura Alzúa, Guillermo Cruces y Laura Ripani. "Welfare Programs and Labor Supply in Developing Countries. Experimental Evidence from Latin America".

- Nro. 94 (Febrero 2010). Ricardo Bebczuk y Diego Battistón. "Remittances and Life Cycle Deficits in Latin America".

- Nro. 93 (Enero, 2010). Guillermo Cruces, Sebastian Galiani y Susana Kidyba. "Payroll Taxes, Wages and Employment: Identification through Policy Changes".

- Nro. 92 (Diciembre, 2009). Mauricio Zunino. "Impactos de la Reinstauración de los Consejos de Salarios sobre la Distribución Salarial en Uruguay: Conclusiones, Hipótesis e Interrogantes".

- Nro. 91 (Diciembre, 2009). María Laura Alzúa, Catherine Rodriguez y Edgar Villa. "The Quality of Life in Prisons: Do Educational Programs Reduce In-prison Conflicts?".

- Nro. 90 (Noviembre, 2009). Diego Battiston, Guillermo Cruces, Luis Felipe Lopez Calva, Maria Ana Lugo y Maria Emma Santos. "Income and Beyond: Multidimensional Poverty in Six Latin American countries".

- Nro. 89 (Octubre, 2009). Mariana Viollaz, Sergio Olivieri y Javier Alejo. "Labor Income Polarization in Greater Buenos Aires".

- Nro. 88 (Septiembre, 2009). Sebastian Galiani. "Reducing Poverty in Latin America and the Caribbean".

- Nro. 87 (Agosto, 2009). Pablo Gluzmann y Federico Sturzenegger. "An Estimation of CPI Biases in Argentina 1985-2005, and its Implications on Real Income Growth and Income Distribution".

- Nro. 86 (Julio, 2009). Mauricio Gallardo Altamirano. "Estimación de Corte Transversal de la Vulnerabilidad y la Pobreza Potencial de los Hogares en Nicaragua".

- Nro. 85 (Junio, 2009). Rodrigo López-Pablos. "Una Aproximación Antropométrica a la Medición de la Pobreza".

- Nro. 84 (Mayo, 2009). Maribel Jiménez y Mónica Jiménez. "La Movilidad Intergeneracional del Ingreso: Evidencia para Argentina". 
- Nro. 83 (Abril, 2009). Leonardo Gasparini y Pablo Gluzmann "Estimating Income Poverty and Inequality from the Gallup World Poll: The Case of Latin America and the Caribbean".

- Nro. 82 (Marzo, 2009). Facundo Luis Crosta. "Reformas Administrativas y Curriculares: El Efecto de la Ley Federal de Educación sobre el Acceso a Educación Media".

- Nro. 81 (Febrero, 2009). Leonardo Gasparini, Guillermo Cruces, Leopoldo Tornarolli y Mariana Marchionni. "A Turning Point? Recent Developments on Inequality in Latin America and the Caribbean".

- Nro. 80 (Enero, 2009). Ricardo N. Bebczuk. "SME Access to Credit in Guatemala and Nicaragua: Challenging Conventional Wisdom with New Evidence".

- Nro. 79 (Diciembre, 2008). Gabriel Sánchez, María Laura Alzúa e Inés Butler. "Impact of Technical Barriers to Trade on Argentine Exports and Labor Markets".

- Nro. 78 (Noviembre, 2008). Leonardo Gasparini y Guillermo Cruces. "A Distribution in Motion: The Case of Argentina".

- Nro. 77 (Noviembre, 2008). Guillermo Cruces y Leonardo Gasparini. "Programas Sociales en Argentina: Alternativas para la Ampliación de la Cobertura".

- Nro. 76 (Octubre, 2008). Mariana Marchionni y Adriana Conconi. "¿Qué y a Quién? Beneficios y Beneficiarios de los Programas de Transferencias Condicionadas de Ingresos".

- Nro. 75 (Septiembre, 2008). Marcelo Bérgolo y Fedora Carbajal. "Brecha Urbano Rural de Ingresos Laborales en Uruguay para el Año 2006: Una Descomposición por Cuantiles".

- Nro. 74 (Agosto, 2008). Matias D. Cattaneo, Sebastian Galiani, Paul J. Gertler, Sebastian Martinez y Rocio Titiunik. "Housing, Health and Happiness".

- Nro. 73 (Agosto, 2008). María Laura Alzúa. "Are Informal Workers Secondary Workers?: Evidence for Argentina".

- Nro. 72 (Julio, 2008). Carolina Díaz-Bonilla, Hans Lofgren y Martín Cicowiez. "Public Policies for the MDGs: The Case of the Dominican Republic".

- Nro. 71 (Julio, 2008). Leonardo Gasparini, Facundo Crosta, Francisco Haimovich, Beatriz Alvarez, Andrés Ham y Raúl Sánchez. "Un Piso de Protección Social en América Latina: Costos Fiscales e Impactos Sociales".

- Nro. 70 (Junio, 2008). Mariana Viollaz. "Polarización de ingresos laborales: Argentina 1992-2006".

- Nro. 69 (Mayo, 2008). Mariana Marchionni, Walter Sosa Escudero y Javier Alejo. "Efectos Distributivos de Esquemas Alternativos de Tarifas Sociales: Una Exploración Cuantitativa". 
- Nro. 68 (Mayo, 2008). Ricardo N. Bebczuk. "Financial Inclusion in Latin America and the Caribbean: Review and Lessons".

- Nro. 67 (Abril, 2008). Mariana Marchionni, Walter Sosa Escudero y Javier Alejo. "La Incidencia Distributiva del Acceso, Gasto y Consumo de los Servicios Públicos".

- Nro. 66 (Abril, 2008). Ricardo N. Bebczuk. "Dolarización y Pobreza en Ecuador".

- Nro. 65 (Marzo, 2008). Walter Sosa Escudero and Anil K. Bera. "Tests for Unbalanced Error Component Models Under Local Misspecication".

- Nro. 64 (Febrero, 2008). Luis Casanova. "Trampas de Pobreza en Argentina: Evidencia Empírica a Partir de un Pseudo Panel".

- Nro. 63 (Enero, 2008). Francisco Franchetti y Diego Battistón. "Inequality in Health Coverage, Empirical Analysis with Microdata for Argentina 2006".

- Nro. 62 (Diciembre, 2007). Adriana Conconi, Guillermo Cruces, Sergio Olivieri y Raúl Sánchez. "E pur si muove? Movilidad, Pobreza y Desigualdad en América Latina".

- Nro. 61 (Diciembre, 2007). Mariana Marchionni, Germán Bet y Ana Pacheco. "Empleo, Educación y Entorno Social de los Jóvenes: Una Nueva Fuente de Información".

- Nro. 60 (Noviembre, 2007). María Gabriela Farfán y María Florencia Ruiz Díaz. "Discriminación Salarial en la Argentina: Un Análisis Distributivo".

- Nro. 59 (Octubre, 2007). Leopoldo Tornarolli y Adriana Conconi. "Informalidad y Movilidad Laboral: Un Análisis Empírico para Argentina".

- Nro. 58 (Septiembre, 2007). Leopoldo Tornarolli. "Metodología para el Análisis de la Pobreza Rural".

- Nro. 57 (Agosto, 2007). Adriana Conconi y Andrés Ham. "Pobreza Multidimensional Relativa: Una Aplicación a la Argentina".

- Nro. 56 (Agosto, 2007). Martín Cicowiez, Luciano Di Gresia y Leonardo Gasparini. "Politicas Públicas y Objetivos de Desarrollo del Milenio en la Argentina".

- Nro. 55 (Julio, 2007). Leonardo Gasparini, Javier Alejo, Francisco Haimovich, Sergio Olivieri y Leopoldo Tornarolli. "Poverty among the Elderly in Latin America and the Caribbean".

- Nro. 54 (Julio, 2007). Gustavo Javier Canavire-Bacarreza y Luís Fernando Lima Soria. "Unemployment Duration and Labor Mobility in Argentina: A Socioeconomic-Based Pre- and Post-Crisis Analysis".

- Nro. 53 (Junio, 2007). Leonardo Gasparini, Francisco Haimovich y Sergio Olivieri. "Labor Informality Effects of a Poverty-Alleviation Program". 
- Nro. 52 (Junio, 2007). Nicolás Epele y Victoria Dowbley. "Análisis Ex-Ante de un Aumento en la Dotación de Capital Humano: El Caso del Plan Familias de Transferencias Condicionadas".

- Nro. 51 (Mayo, 2007). Jerónimo Carballo y María Bongiorno. "Vulnerabilidad Individual: Evolución, Diferencias Regionales e Impacto de la Crisis. Argentina 1995 - 2005".

- Nro. 50 (Mayo, 2007). Paula Giovagnoli. "Failures in School Progression".

- Nro. 49 (Abril, 2007). Sebastian Galiani, Daniel Heymann, Carlos Dabús y Fernando Tohmé. "Land-Rich Economies, Education and Economic Development".

- Nro. 48 (Abril, 2007). Ricardo Bebczuk y Francisco Haimovich. "MDGs and Microcredit: An Empirical Evaluation for Latin American Countries".

- Nro. 47 (Marzo, 2007). Sebastian Galiani y Federico Weinschelbaum. "Modeling Informality Formally: Households and Firms".

- Nro. 46 (Febrero, 2007). Leonardo Gasparini y Leopoldo Tornarolli. "Labor Informality in Latin America and the Caribbean: Patterns and Trends from Household Survey Microdata".

- Nro. 45 (Enero, 2007). Georgina Pizzolitto. "Curvas de Engel de Alimentos, Preferencias Heterogéneas y Características Demográficas de los Hogares: Estimaciones para Argentina".

- Nro. 44 (Diciembre, 2006). Rafael Di Tella, Sebastian Galiani y Ernesto Schargrodsky. "Crime Distribution and Victim Behavior during a Crime Wave".

- Nro. 43 (Noviembre, 2006). Martín Cicowiez, Leonardo Gasparini, Federico Gutiérrez y Leopoldo Tornarolli. "Areas Rurales y Objetivos de Desarrollo del Milenio en America Latina y El Caribe".

- Nro. 42 (Octubre, 2006). Martín Guzmán y Ezequiel Molina. "Desigualdad e Instituciones en una Dimensión Intertemporal".

- Nro. 41 (Septiembre, 2006). Leonardo Gasparini y Ezequiel Molina. "Income Distribution, Institutions and Conflicts: An Exploratory Analysis for Latin America and the Caribbean".

- Nro. 40 (Agosto, 2006). Leonardo Lucchetti. "Caracterización de la Percepción del Bienestar y Cálculo de la Línea de Pobreza Subjetiva en Argentina".

- Nro. 39 (Julio, 2006). Héctor Zacaria y Juan Ignacio Zoloa. "Desigualdad y Pobreza entre las Regiones Argentinas: Un Análisis de Microdescomposiciones".

- Nro. 38 (Julio, 2006). Leonardo Gasparini, Matías Horenstein y Sergio Olivieri. "Economic Polarisation in Latin America and the Caribbean: What do Household Surveys Tell Us?". 
- Nro. 37 (Junio, 2006). Walter Sosa-Escudero, Mariana Marchionni y Omar Arias. "Sources of Income Persistence: Evidence from Rural El Salvador".

- Nro. 36 (Mayo, 2006). Javier Alejo. "Desigualdad Salarial en el Gran Buenos Aires: Una Aplicación de Regresión por Cuantiles en Microdescomposiciones".

- Nro. 35 (Abril, 2006). Jerónimo Carballo y María Bongiorno. "La Evolución de la Pobreza en Argentina: Crónica, Transitoria, Diferencias Regionales y Determinantes (1995-2003)".

- Nro. 34 (Marzo, 2006). Francisco Haimovich, Hernán Winkler y Leonardo Gasparini. "Distribución del Ingreso en América Latina: Explorando las Diferencias entre Países".

- Nro. 33 (Febrero, 2006). Nicolás Parlamento y Ernesto Salinardi. "Explicando los Cambios en la Desigualdad: Son Estadísticamente Significativas las Microsimulaciones? Una Aplicación para el Gran Buenos Aires".

- Nro. 32 (Enero, 2006). Rodrigo González. "Distribución de la Prima Salarial del Sector Público en Argentina".

- Nro. 31 (Enero, 2006). Luis Casanova. "Análisis estático y dinámico de la pobreza en Argentina: Evidencia Empírica para el Periodo 1998-2002".

- Nro. 30 (Diciembre, 2005). Leonardo Gasparini, Federico Gutiérrez y Leopoldo Tornarolli. "Growth and Income Poverty in Latin America and the Caribbean: Evidence from Household Surveys".

- Nro. 29 (Noviembre, 2005). Mariana Marchionni. "Labor Participation and Earnings for Young Women in Argentina".

- Nro. 28 (Octubre, 2005). Martín Tetaz. "Educación y Mercado de Trabajo".

- Nro. 27 (Septiembre, 2005). Matías Busso, Martín Cicowiez y Leonardo Gasparini. "Ethnicity and the Millennium Development Goals in Latin America and the Caribbean".

- Nro. 26 (Agosto, 2005). Hernán Winkler. "Monitoring the Socio-Economic Conditions in Uruguay".

- Nro. 25 (Julio, 2005). Leonardo Gasparini, Federico Gutiérrez y Guido G. Porto. "Trade and Labor Outcomes in Latin America's Rural Areas: A Cross-Household Surveys Approach".

- Nro. 24 (Junio, 2005). Francisco Haimovich y Hernán Winkler. "Pobreza Rural y Urbana en Argentina: Un Análisis de Descomposiciones".

- Nro. 23 (Mayo, 2005). Leonardo Gasparini y Martín Cicowiez. "Meeting the Poverty-Reduction MDG in the Southern Cone". 
- Nro. 22 (Abril, 2005). Leonardo Gasparini y Santiago Pinto. "Equality of Opportunity and Optimal Cash and In-Kind Policies".

- Nro. 21 (Abril, 2005). Matías Busso, Federico Cerimedo y Martín Cicowiez. "Pobreza, Crecimiento y Desigualdad: Descifrando la Última Década en Argentina".

- Nro. 20 (Marzo, 2005). Georgina Pizzolitto. "Poverty and Inequality in Chile: Methodological Issues and a Literature Review".

- Nro. 19 (Marzo, 2005). Paula Giovagnoli, Georgina Pizzolitto y Julieta Trías. "Monitoring the Socio-Economic Conditions in Chile".

- Nro. 18 (Febrero, 2005). Leonardo Gasparini. "Assessing Benefit-Incidence Results Using Decompositions: The Case of Health Policy in Argentina".

- Nro. 17 (Enero, 2005). Leonardo Gasparini. "Protección Social y Empleo en América Latina: Estudio sobre la Base de Encuestas de Hogares".

- Nro. 16 (Diciembre, 2004). Evelyn Vezza. "Poder de Mercado en las Profesiones Autorreguladas: El Desempeño Médico en Argentina".

- Nro. 15 (Noviembre, 2004). Matías Horenstein y Sergio Olivieri. "Polarización del Ingreso en la Argentina: Teoría y Aplicación de la Polarización Pura del Ingreso".

- Nro. 14 (Octubre, 2004). Leonardo Gasparini y Walter Sosa Escudero. "Implicit Rents from Own-Housing and Income Distribution: Econometric Estimates for Greater Buenos Aires".

- Nro. 13 (Septiembre, 2004). Monserrat Bustelo. "Caracterización de los Cambios en la Desigualdad y la Pobreza en Argentina Haciendo Uso de Técnicas de Descomposiciones Microeconometricas (1992-2001)".

- Nro. 12 (Agosto, 2004). Leonardo Gasparini, Martín Cicowiez, Federico Gutiérrez y Mariana Marchionni. "Simulating Income Distribution Changes in Bolivia: a Microeconometric Approach".

- Nro. 11 (Julio, 2004). Federico H. Gutierrez. "Dinámica Salarial y Ocupacional: Análisis de Panel para Argentina 1998-2002".

- Nro. 10 (Junio, 2004). María Victoria Fazio. "Incidencia de las Horas Trabajadas en el Rendimiento Académico de Estudiantes Universitarios Argentinos".

- Nro. 9 (Mayo, 2004). Julieta Trías. "Determinantes de la Utilización de los Servicios de Salud: El Caso de los Niños en la Argentina".

- Nro. 8 (Abril, 2004). Federico Cerimedo. "Duración del Desempleo y Ciclo Económico en la Argentina".

- Nro. 7 (Marzo, 2004). Monserrat Bustelo y Leonardo Lucchetti. "La Pobreza en Argentina: Perfil, Evolución y Determinantes Profundos (1996, 1998 Y 2001)". 
- Nro. 6 (Febrero, 2004). Hernán Winkler. "Estructura de Edades de la Fuerza Laboral y Distribución del Ingreso: Un Análisis Empírico para la Argentina".

- Nro. 5 (Enero, 2004). Pablo Acosta y Leonardo Gasparini. "Capital Accumulation, Trade Liberalization and Rising Wage Inequality: The Case of Argentina".

- Nro. 4 (Diciembre, 2003). Mariana Marchionni y Leonardo Gasparini. "Tracing Out the Effects of Demographic Changes on the Income Distribution. The Case of Greater Buenos Aires".

- Nro. 3 (Noviembre, 2003). Martín Cicowiez. "Comercio y Desigualdad Salarial en Argentina: Un Enfoque de Equilibrio General Computado".

- Nro. 2 (Octubre, 2003). Leonardo Gasparini. "Income Inequality in Latin America and the Caribbean: Evidence from Household Surveys".

- Nro. 1 (Septiembre, 2003). Leonardo Gasparini. "Argentina's Distributional Failure: The Role of Integration and Public Policies". 